\title{
Journal of Environmental Chemical Engineering \\ The impact of the particle size of meat and bone meal (MBM) incineration ash on phosphate precipitation and phosphorus recovery \\ --Manuscript Draft--
}

\begin{tabular}{|c|c|}
\hline Manuscript Number: & JECE-D-20-04800R2 \\
\hline Article Type: & Research Paper \\
\hline Keywords: & $\begin{array}{l}\text { biomass combustion; Bottom ash; Phosphorus adsorption; Apatite; Acid dissolution; } \\
\text { Calcium phosphate precipitation }\end{array}$ \\
\hline Corresponding Author: & $\begin{array}{l}\text { Hua-jun Huang, Ph.D. } \\
\text { Jiangxi Agricultural University } \\
\text { Nanchang, CHINA }\end{array}$ \\
\hline First Author: & Lijian Leng \\
\hline \multirow[t]{6}{*}{ Order of Authors: } & Lijian Leng \\
\hline & Weijin Zhang \\
\hline & Hailong Li \\
\hline & Anna A. Bogush \\
\hline & Julia A. Stegemann \\
\hline & Hua-jun Huang, Ph.D. \\
\hline Abstract: & $\begin{array}{l}\text { MBM ash was characterised and used for phosphate wastewater treatment and } \\
\text { phosphorus recovery. The MBM-BA with size }>250 \mu \mathrm{m} \text { accounted for } \sim 80 \% \text { and } \\
\text { distributed evenly in the }>1000,500-1000 \text {, and } 250-500 \mu \mathrm{m} \text { fractions, while MBM- } \\
\text { APCr distributed evenly among the } 250-500,125-250 \text {, and }<125 \mu \mathrm{m} \text { fractions. The P } \\
\text { content in MBMA ranged } 7.9-15.6 \% \text { depending on particle size, and P content in } \\
\text { MBM-BA (14.33\%) was higher than MBM-APCr }(9.28 \%) \text {. P in both MBM-BA and MBM- } \\
\text { APCr was mainly HAP as analysed by XRD. Decreased HAP and increased Ca(OH)2 } \\
\text { were observed with decreasing particle size of MBM-BA. NaCl and Na2SO4.3K2SO4 } \\
\text { were found with high content in the MBM-APCr, and increased as decreasing size. Ash } \\
\text { type, pH, and particle size had significant effects on phosphate removal from synthetic } \\
\text { wastewater. Phosphate removal capacities of } 13.5-279 \text { and } 13.5-36.6 \text { mg PO43-/g } \\
\text { ash were obtained using MBM-BA and MBM-APCr, respectively. Phosphate removal } \\
\text { capacities were particle size-dependent; the smaller the size, the higher the capacity: } \\
\text { those for MBM-BA of size }>1000 \mu \text { m and }<63 \mu m \text { were } 13.5 \text { and } 279 \text { mg/g, } \\
\text { respectively. Equilibrium pH }>8 \text { was favourable to P removal. Based on the } \\
\text { compositions of the solid phases, extracts before and after treatment, and Ca/P ratio } \\
1.22-1.73, \text { the phosphate removal mechanisms were dominated by HAP } \\
\text { crystallisation/precipitation. Using MBM-BA for wastewater treatment increased its P } \\
\text { content to } 16.30 \% \text {. Depending on particle size, the acid consumption for P recovery of } \\
84 \% \text { from MBM-BA was } 2.6-3.0 \text { mM H+/mM P. Strategies for management and } \\
\text { utilisation of MBMA according to these findings were proposed. }\end{array}$ \\
\hline
\end{tabular}




\section{Graphic abstract}

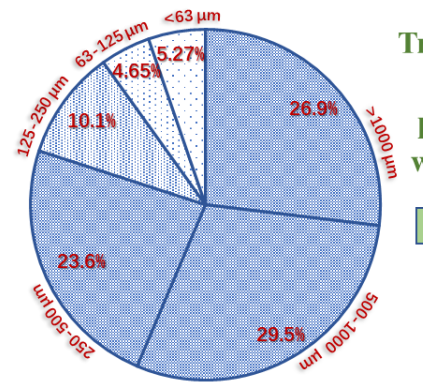

$P$ content in MBM-BA 7.9 $15.6 \%$ (size-dependent)

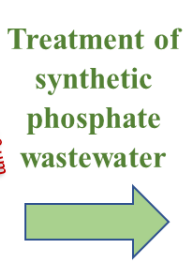

$\mathrm{PO}_{4}{ }^{3-}$ removal capacities: $13.5-279$ $\mathrm{mg} / \mathrm{g}$ (size-dependent) है.
Acid dissolution for $P$ recovery

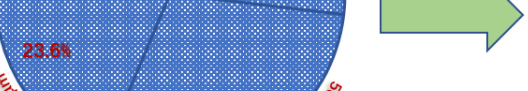
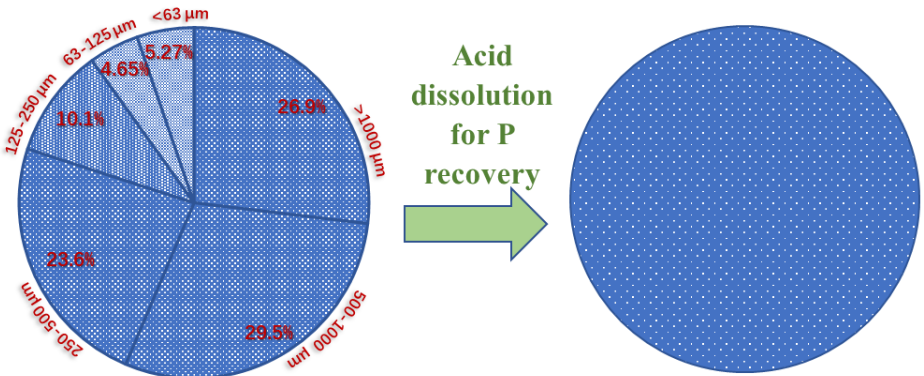

Acid consumption: 2.6-3.0 mM $\mathrm{H}^{+} / \mathrm{mM} \mathrm{P}$ (size-dependent)

Pcontent: $16-17 \%$ 畔 15-16\% $14-15 \%$ : 12-13\% $\quad$ 9-10\% $\quad 7-8 \%$ 


\section{Highlights}

- Meat and bone meal (MBM) has varied particle size, bottom ash (BA) has larger size

- Ash component hydroxyapatite increases, portlandite decreases with increasing size

- $\mathrm{PO}_{4}{ }^{3-}$ removal of $279 \mathrm{mg} / \mathrm{g}$ MBM-BA achieved, it decreases as increasing particle size

- Acid consumption (AC) of $2.7 \mathrm{M} \mathrm{H}^{+} / \mathrm{M} \mathrm{P}$ and $\mathrm{P}$ recovery rate $84 \%$ were obtained

- $\mathrm{AC}$ decreased from 2.8-176 to $2.6-3.0 \mathrm{M} \mathrm{H}^{+} / \mathrm{M} \mathrm{P}$ after wastewater treatment by MBM-BA 


\section{The impact of the particle size of meat and bone meal (MBM)}

\section{incineration ash on phosphate precipitation and phosphorus recovery}

Lijian Leng a , Weijin Zhang ${ }^{\text {a }}$, Hailong Li ${ }^{\text {a }}$, Anna A. Bogush ${ }^{\text {b }}$, Julia A. Stegemann ${ }^{\text {b, *, }}$ Huajun Huang ${ }^{c}$ *

${ }^{\text {a }}$ School of Energy Science and Engineering, Central South University, Changsha, Hunan 410083, China

${ }^{\mathrm{b}}$ Department of Civil, Environmental \& Geomatic Engineering (CEGE Centre for Resource Efficiency \& the Environment (CREE), University College London, Chadwick Building, Gower Street, London WC1E 6BT, UK

${ }^{c}$ School of Land Resources and Environment, Jiangxi Agricultural University, Nanchang 330045, China

\section{* Corresponding authors}

E-mail addresses:Iljchs@126.com (L.Leng); j.stegemann@ucl.ac.uk (J.A. Stegemann); huanghuajun2004@126.com (H. Huang). 
Abstract: Meat and bone meal (MBM) ash was characterised and used for phosphate wastewater treatment and phosphorus recovery. The bottom ash (MBM-BA) with size $>250 \mu \mathrm{m}$ accounted for $\sim 80 \%$ and distributed evenly in the $>1000 \mu \mathrm{m}, 500-1000 \mu \mathrm{m}$, and 250-500 $\mu \mathrm{m}$ fractions, while air pollution control residue (MBM-APCr) distributed evenly among the $250-500 \mu \mathrm{m}, 125-250 \mu \mathrm{m}$, and $<125 \mu \mathrm{m}$ fractions. The P content in ash ranged 7.9-15.6\% depending on particle size, and P content in MBM-BA (14.33\%) was higher than MBM-APCr (9.28\%). P in both MBM-BA and MBM-APCr was mainly hydroxyapatite (HAP) as analysed by X-ray powder diffraction (XRD). Decreased HAP and increased $\mathrm{Ca}(\mathrm{OH})_{2}$ were observed with decreasing particle size of MBM-BA. NaCl and $\mathrm{Na}_{2} \mathrm{SO}_{4} \cdot 3 \mathrm{~K}_{2} \mathrm{SO}_{4}$ were found with high content in the MBM-APCr, and increased as decreasing size. Ash type, $\mathrm{pH}$, and particle size had significant effects on phosphate removal from synthetic wastewater. Phosphate removal capacities of 13.5-279 and 13.5-36.6 $\mathrm{mg} \mathrm{PO}_{4}{ }^{3-} / \mathrm{g}$ ash were obtained using MBM-BA and MBM-APCr, respectively. Phosphate removal capacities were particle size-dependent; the smaller the size, the higher the capacity: those for MBM-BA of size $>1000 \mu \mathrm{m}$ and $<63 \mu \mathrm{m}$ were 13.5 and $279 \mathrm{mg} / \mathrm{g}$, respectively. Equilibrium $\mathrm{pH}>8$ was favourable to $\mathrm{P}$ removal. Based on the compositions of the solid phases, extracts before and after treatment, and $\mathrm{Ca} / \mathrm{P}$ ratio $1.22-1.73$, the phosphate removal mechanisms were dominated by HAP crystallisation/precipitation. Using MBM-BA for wastewater treatment increased its $\mathrm{P}$ content to $16.30 \%$. Depending on particle size, the acid consumption for P recovery of 84\% from MBM-BA was 2.6-3.0 $\mathrm{mM} \mathrm{H}^{+} / \mathrm{mM} \mathrm{P.} \mathrm{Strategies} \mathrm{for} \mathrm{management} \mathrm{and}$ utilisation of MBMA according to these findings were proposed.

Keywords: Biomass combustion; Bottom ash; Phosphorus adsorption; Apatite; Acid dissolution; Calcium phosphate precipitation 


\section{Introduction}

Meat and bone meal (MBM), a by-product from rendering that represents about $30 \%$ of the live weight of an animal, has a high phosphorus (P) content. It was historically used as a raw material for animal feed production before the outbreak of bovine spongiform encephalopathy (BSE, so-called "mad cow disease") in the 1980-90s, mainly in the UK with a smaller number of cases globally (Arvanitoyannis and Ladas, 2008). Since then, the use of MBM in animal feed production has been totally or partially restricted by regulation European Commission (EC) No. 1774/2002 and its amendment No. 808/2003 (Cascarosa et al., 2012). Thus, a large amount of MBM is now generally disposed of by incineration, co-incineration, or other thermochemical treatment methods, such as gasification, to produce energy or heat and remove BSE transmission risks (Cascarosa et al., 2012; Leng et al., 2018b). However, the increasing application of MBM incineration is resulting in mounting quantities of MBM ash (MBMA), including bottom ash (BA) and air pollution control residue (APCr) with a production ratio around $6: 1$, which is landfilled, although it has a valuable phosphorus content of up to $\sim 15 \%$ (Coutand et al., 2008; Deydier et al., 2005). In Europe, $1 \mathrm{Mt} / \mathrm{y}$ MBM would produce $\sim 350 \mathrm{kt} / \mathrm{y}$ of MBMA $(\sim 35 \%$ of MBM), containing $>50 \mathrm{kt}$ of $\mathrm{P}$, if it was all used for energy production (EFPRA, 2019).

Phosphorus is an essential plant nutrient to maintain agricultural yields and is an essential element for all lifeforms. Global reserves are depleting due to the widespread global use of $\mathrm{P}$ in fertilisers over the past century (Mazloomi et al., 2019; Yousefi et al., 2019). A static lifetime of $P$ reserve of $~ 350$ years was estimated in 2010 , assuming no increase in P demand (IFDC, 2010). Given that P demand is increasing, and phosphate rock reserves are limited to particular geographic regions (Morocco and Moroccan occupied Western Sahara, China, and the US (Cordell, 2010; Elser and Bennett, 2011)), 
regions such as Europe, where there is almost no phosphate rock reserve, are under pressure to "mine" P from P-bearing wastes (Cordell et al., 2009; Mayer et al., 2016; Sattari et al., 2012; Tilman et al., 2001; Tilman and Lehman, 1987). The EC has added phosphate rock to the list of the "20 Critical Raw Materials" in 2014 for which supply security is at risk, and economic importance is high ("Anonymous Critical Raw Materials," 2014). Meanwhile, regulations and policies are being proposed in countries such as Switzerland, Germany, and Australia for the obligatory recovery of $\mathrm{P}$ from sewage sludge and slaughterhouse waste such as MBM (Hukari et al., 2016; Wiśniowska et al., 2019).

Furthermore, most of the $\mathrm{P}$ mined worldwide to date has been dispersed in the hydrosphere and pedosphere (Cordell et al., 2009; Elser and Bennett, 2011; MacDonald et al., 2011). The discharge of $\mathrm{P}$ and other nutrients such as nitrogen in the hydrosphere has caused a global problem-eutrophication of numerous lakes and rivers and coastal waters (Chen et al., 2015; Conley et al., 2009; Leng et al., 2018c). Municipal wastewater with low $\mathrm{P}$ concentrations $(\sim 10 \mathrm{mg} / \mathrm{L})$ but large volumes $\left(5 \times 10^{10} \mathrm{~m}^{3} / \mathrm{y}\right.$ in Europe, based on a nominal per capita production of $0.200 \mathrm{~m}^{3} / \mathrm{d}$ ) is one of the major sources, and industrial wastewaters, such as abattoir wastewater (P up to $200 \mathrm{mg} / \mathrm{L}$; European generation of $\sim 6 \times 10^{8} \mathrm{~m}^{3} / \mathrm{y}$, based on a conservative nominal assumption of $0.05 \mathrm{~m}^{3} /$ chicken and $1 \mathrm{~m}^{3} /$ other animal (Mittal, 2004; Pol Marquer et al., 2019)), and phosphate industry wastewater with low $\mathrm{pH}$ and high $\mathrm{P}$ concentrations (e.g., $\mathrm{pH}$ of $\sim 2.8$ and $\mathrm{P}$ concentration of $\sim 100 \mathrm{mg} / \mathrm{L}$ (Grzmil and Wronkowski, 2006)) also make considerable contributions to eutrophication. Therefore, the removal and recovery of $\mathrm{P}$ from wastewater discharge systems is essential to prevent eutrophication and protect ecosystems ( $\mathrm{Li}$ et al., 2015).

Removal of P from wastewater using biomass and its ash (Hermassi et al., 2017; Leng et al., 2019b; Niu et al., 2016; Rashidi and Yusup, 2016), biochar (Li et al., 2017; Liang 
et al., 2014; Shepherd et al., 2017), or other materials (Ali and Gupta, 2006; Blanco et al., 2016; van Loosdrecht and Brdjanovic, 2014) can be an efficient and cost-effective wastewater treatment technology. Interestingly, P-bearing materials such as animal bones and their chars (Jang and Kang, 2002; Leng et al., 2019b; N. Vassilev et al., 2013) and phosphate rock (Molle et al., 2005a; Troesch et al., 2016) have also been tested as reagents for $\mathrm{P}$ removal, whereby apatite in these materials act as seed crystals for phosphate precipitation by the formation of hydroxyapatite [HAP, $\left.\mathrm{Ca}_{5}\left(\mathrm{PO}_{4}\right)_{3}(\mathrm{OH})\right]$. MBMA has a similar composition to these materials, with HAP and tricalcium phosphate being the dominant minerals, and is thus also a candidate seed material for effective P removal from wastewater (Coutand et al., 2008; Deydier et al., 2005; Leng et al., 2019b). The differences in calcium sources have a considerable impact on P removal from wastewater by precipitation/crystallization (Leng et al., 2019b). The varied composition for MBMA with different sources and sizes could have a significant effect on P removal potential. However, previous research has overlooked the importance of ash particle size in P removal from wastewater and $\mathrm{P}$ recovery by acid dissolution.

In the present study, the varied composition of MBMA with different sizes was analysed first. Then the effects of MBMA particle size, contact time, and $\mathrm{pH}$ on phosphate removal from wastewater were examined. The $\mathrm{P}$ removal mechanisms were studied to enable process design and optimisation. Moreover, the use of acid dissolution to enhance P recovery from MBMA was assessed. Finally, strategies for management and utilisation of MBMA were proposed. This study aims to make contributions to the characterisation, application, and management of MBMA.

\section{Materials and methods}

\subsection{Characterisation}

MBM-BA and MBM-APCr, with a weight ratio of approximately 6:1, were the bottom ash and air pollution control residue, respectively, collected from a UK 
industrial power plant with MBM as the mono-energy source. The plant uses moving grate incinerators with a combustion temperature of $850{ }^{\circ} \mathrm{C}$, dry discharge of bottom ash, and dry scrubbing of the flue gas. The ashes were collected without treatment, and MBM-BA was sieved into six particle size fractions: $>1000 \mu \mathrm{m}, 500-1000 \mu \mathrm{m}, 250$ $500 \mu \mathrm{m}, 125-250 \mu \mathrm{m}, 63-125 \mu \mathrm{m}$, and $<63 \mu \mathrm{m}$, while MBM-APCr was sieved into four fractions (no particle was $>500 \mu \mathrm{m}$ ): $250-500 \mu \mathrm{m}, 125-250 \mu \mathrm{m}, 63-125 \mu \mathrm{m}$, and $<63$ $\mu \mathrm{m}$. The mass of each fraction was determined in triplicate. The specific gravities of the MBMA fractions were measured five times using a Micromeritics AccuPyn 1330 helium pycnometer. The different particle size fractions were ground to $<63 \mu \mathrm{m}$ for use in the analyses and experiments unless specified.

The total $\mathrm{P}$ content in each particle size fraction was analysed colourimetrically (at $880 \mathrm{~nm}$ ) by reacting with ammonium molybdate using ascorbic acid as the reducing agent (Murphy and Riley, 1962) after acid digestion using potassium persulfate at 150 ${ }^{\circ} \mathrm{C}$ for $4.0 \mathrm{~h}$, and filtration. The different particle size fractions were subjected to total digestion using $\mathrm{HNO}_{3}: \mathrm{HClO}_{4}: \mathrm{H}_{2} \mathrm{O}_{2}(\mathrm{v}, 30 \%)$ = 5:5:3, v/v) (Leng et al., 2018a, 2020) before chemical analysis for $\mathrm{Ca}, \mathrm{Na}, \mathrm{K}, \mathrm{Mg}, \mathrm{Al}, \mathrm{Fe}, \mathrm{Zn}, \mathrm{Cr}, \mathrm{Mn}, \mathrm{Cu}, \mathrm{Ni}$, and $\mathrm{Pb}$ by inductively coupled plasma optical emission spectroscopy (ICP-OES). The digestion procedure and analysis were repeated three times.

X-ray powder diffraction (XRD) (Bruker D8 advance, Germany) was applied to analyse the crystalline composition of the MBMA before and after its use in wastewater treatment, over the scanning range of $5^{\circ}-70^{\circ}(2 \theta)$. The X-ray source of $\mathrm{Cu} \mathrm{K}_{\alpha}$ radiation (60 KV and $80 \mathrm{~mA}$ ) and a scanning speed of 4 sec/step (step size of $0.05^{\circ}$ ) were used. Jade software version 6.5 (Materials Data Inc., Livermore, USA) was used for the XRD data analysis.

Fourier transform infrared spectroscopy (FTIR), using a Thermo-Fischer Scientific Nicolet 670 spectrometer with a wavelength range of $400-4000 \mathrm{~cm}^{-1}$, was also applied 
to the MBMA before and after its use in wastewater treatment.

\subsection{Phosphorus removal from wastewater by meat and bone meal ash}

Synthetic P-containing wastewater with a $\mathrm{PO}_{4}{ }^{3-}$ concentration of $300 \mathrm{mg} / \mathrm{L}(3.16$ $\mathrm{mM} / \mathrm{L}$ ) was prepared by dissolving anhydrous analytical grade $\mathrm{K}_{2} \mathrm{HPO}_{4}$ in milli-Q water. Experiments to use MBMA to remove $\mathrm{P}$ from this wastewater were conducted at an MBMA/wastewater ratio of $40 \mathrm{mg} / 40 \mathrm{~mL}(1 \mathrm{~g} / \mathrm{L})$, room temperature $\left(\sim 20^{\circ} \mathrm{C}\right)$, and endover-end tumble speed of $30 \mathrm{rpm}$. Preliminary experiments examined the effect of contact times from 0-120 min on P removal by MBM-BA and MBM-APCr without acid addition. A contact time of 60 min was then used in subsequent experiments with MBM-BA, which used $\mathrm{HNO}_{3}$ to adjust the $\mathrm{pH}$ of the synthetic P-containing wastewater with acid loads of $0,0.5,1.0,2.0,3.0,4.0,5.0,6.0,8.0,10.0,12.0$, and $15.0 \mathrm{mM} \mathrm{H}^{+} / \mathrm{g}$ ash to study the effect of $\mathrm{pH}$ on $\mathrm{P}$ removal. After the $\mathrm{P}$ removal process, the mixtures were maintained in the tumble rotator to allow for natural sedimentation (all showed good settleability), and then the mixtures were centrifuged at $4000 \mathrm{rpm}$ for $5 \mathrm{~min}$ to achieve the complete phase separation.

Phosphate concentrations were analysed colourimetrically in extracts from filtering the resulting slurries through $0.45 \mu \mathrm{m}$ membrane paper. Eq. 1 was then used to calculate the $\mathrm{PO}_{4}{ }^{3-}$ uptakes of the ashes $\left(q_{e}, \mathrm{mg} \mathrm{g}^{-1}\right)$ :

$$
q_{e}=V^{*}\left(C_{o}-C_{e}\right) / m
$$

where $C_{o}$ and $C_{e}$ are the initial and equilibrium (i.e., at the end of the experiment) $\mathrm{PO}_{4}{ }^{3-}$ concentrations $\left(\mathrm{mg} \mathrm{L}^{-1}\right)$, respectively; $V$ and $m$ is the volume of the synthetic wastewater $(\mathrm{mL})$ and the mass of the MBMA $(\mathrm{mg})$, respectively.

Control experiments examined whether there was any leaching of P from the MBMBA in the absence of the phosphate. Phosphate-free milli-Q water (instead of wastewater) was mixed with MBM-BA, using acid doses of $0.0,12.0$, and $16.0 \mathrm{mM}$ $\mathrm{HNO}_{3} / \mathrm{g}$ for all the MBM-BA fractions; and 0.5, for fraction $>1000 \mu \mathrm{m}$ only; 1.0 , for 
fraction $500-1000 \mu \mathrm{m} ; 2.0$, for whole sample and fraction $250-500 \mu \mathrm{m} ; 3.0$, for fraction 125-250 $\mu \mathrm{m}$; 5.0, for fraction $63-125 \mu \mathrm{m}$, and $6.0 \mathrm{mM} \mathrm{HNO} / \mathrm{g}$, for fraction $<63 \mu \mathrm{m}$. With the same acid dose, the validation experiments were conducted to assess the phosphate removal capacities of each ash fraction when it was used without grinding into particle size $<63 \mu \mathrm{m}$.

To study the $\mathrm{P}$ removal mechanisms, cation $\left(\mathrm{Li}^{+}, \mathrm{Na}^{+}, \mathrm{K}^{+}, \mathrm{Mg}^{2+}, \mathrm{Ca}^{2+}\right.$, and $\left.\mathrm{NH}_{4}^{+}\right)$ concentrations in the wastewater following its treatment using MBM-BA at different pHs (acid doses) and control experiments with MBMA without $\mathrm{P}$ were analysed by a Dionex AQUION ion chromatograph (IC). The equilibrium $\mathrm{pH}$ values at the end of the P removal experiments were also recorded.

\subsection{Phosphorus recovery}

Acid dissolution with acid doses of 12 and $16 \mathrm{mM} \mathrm{H}^{+} / \mathrm{g}$ ash $\left(6\right.$ and $8 \mathrm{mM} \mathrm{H}_{2} \mathrm{SO}_{4} / \mathrm{g}$ ash) at a solid/liquid ratio of $0.1 \mathrm{~g} / 10 \mathrm{~mL}(1 / 100)$ was used to recover P from the MBMBA before and after its use for P removal from the synthetic wastewater.

The experiments in Sections 2.2 and 2.3 were triplicated.

\section{Results and discussions}

\subsection{Characterisation of meat and bone meal ash}

The particle size distributions of the MBM-BA and MBM-APCr are shown in Table 1. The fraction $>250 \mu \mathrm{m}$ accounted for about $80 \%$ of the MBM-BA, but only $33.0 \%$ of the MBM-APCr. The larger-size particles of MBM-BA had higher densities and were distributed almost evenly in the $>1000 \mu \mathrm{m}, 500-1000 \mu \mathrm{m}$, and $250-500 \mu \mathrm{m}$ fractions, while the smaller-size particles of MBM-APCr had lower densities and were mainly distributed among the $250-500 \mu \mathrm{m}, 125-250 \mu \mathrm{m}$, and $<125 \mu \mathrm{m}$ fractions. These observations are consistent with MBM-BA being the heavy non-combustible minerals, rich in lithophilic elements, remaining behind on the grate after combustion; MBMAPCr is mainly fly ash, smaller lighter particles that were entrained in the stack gas and 
captured in the air pollution control system together with relative light reaction products from acid gas $(\mathrm{Cl}, \mathrm{S})$ removal.

The elemental compositions of the MBMA fractions indicate that $\mathrm{P}$ and $\mathrm{Ca}$ are the dominant elements (Table 1). The total P content of MBMA (for both MBM-BA and MBM-APCr) varies depending on the particle size. The larger the size, the higher the $\mathrm{P}$ content (Table 1). A P content as high as $\sim 15 \%$ was observed for particles with a size larger than $250 \mu \mathrm{m}$; the $\mathrm{P}$ content for MBM-BA of size $<63 \mu \mathrm{m}$ was $7.90 \%$ while that for MBM-APCr of the same size was only $3.87 \%$ (Table 1). $\mathrm{P}$ contents of $14.33 \%\left(\mathrm{P}_{2} \mathrm{O}_{5}\right.$ $32.82 \%)$ and $9.28 \%\left(\mathrm{P}_{2} \mathrm{O}_{5} 21.25 \%\right)$ were observed for the whole, unfractionated, MBMBA and MBM-APCr, respectively, which are in the same order of magnitude as those of natural phosphate rocks $[4,36]$. The higher $\mathrm{P}$ content in larger-size particles is because they were dominated by bone residues, whereas the smaller-size particles were dominated by meat residues and reagents such as $\mathrm{Ca}(\mathrm{OH})_{2} / \mathrm{CaO}$.

The $\mathrm{Ca}$ concentration of MBM-BA is around $35 \%$, with the $\mathrm{Ca} / \mathrm{P}$ molar ratio increasing from 1.72 for the largest particle size fraction $(>1000 \mu \mathrm{m})$ to 3.61 for the smallest $(<63 \mu \mathrm{m})$. The $\mathrm{Ca} / \mathrm{P}$ molar ratio of MBM-APCr was around 1.7 for all the fractions, with the Ca concentration decreasing with particle size (along with $\mathrm{P}$ ), from $32 \%$ in the largest fraction to $9 \%$ in the smallest. The comparison of the Ca/P molar ratio in MBMA to that of the commonly seen calcium phosphates (Table 2) suggests the possible presence of HAP and other calcium salts (Chow, 2001). HAP is the primary constituent of bone, which is a main component of MBM. HAP, which has a dehydroxylation temperature of about $900{ }^{\circ} \mathrm{C}$ in the air (Tõnsuaadu et al., 2012), is unlikely to be substantially decomposed at power plants with a peak combustion temperature of $\sim 850{ }^{\circ} \mathrm{C}$. Some decomposition may occur in localised hotspots on the grate, but was not indicated by the mineralogical analysis.

HAP was confirmed by XRD, with the amount decreasing with particle size as was 
observed for P (Fig. 1). HAP and other apatites have also been identified as the major P component in MBMA by previous researchers (Bogush et al., 2018; Coutand et al., 2008), which is consistent with its origin from the bone (Rey et al., 2009). P, in the form of HAP in MBMA, is relatively insoluble under alkaline, neutral, and mildly acidic conditions (Leng et al., 2019a).

Other phases identified in MBM-BA include calcite $\left(\mathrm{CaCO}_{3}\right)$, portlandite $\left(\mathrm{Ca}(\mathrm{OH})_{2}\right)$, calcium sulphate $\left(\mathrm{CaSO}_{4}\right)$, and quartz $\left(\mathrm{SiO}_{2}\right)$. High contents of halite $(\mathrm{NaCl})$ and aphthitalite $\left[\mathrm{K}_{3} \mathrm{Na}\left(\mathrm{SO}_{4}\right)_{2} / \mathrm{Na}_{2} \mathrm{SO}_{4} \cdot 3 \mathrm{~K}_{2} \mathrm{SO}_{4}\right]$ were identified in $\mathrm{MBM}-\mathrm{APCr}$, in addition to $\mathrm{CaCO}_{3}$ and $\mathrm{SiO}_{2}$ (Fig. $1 \mathrm{~b}$ ). $\mathrm{Cl}$ and $\mathrm{S}$ species were volatilized during $\mathrm{MBM}$ combustion and enriched in the MBM-APCr by reprecipitation in the air pollution control system(S. V. Vassilev et al., 2013a, 2013b).

There is no clear trend in the distribution of $\mathrm{Mg}, \mathrm{Al}, \mathrm{Fe}, \mathrm{Cr}, \mathrm{Cu}$ or $\mathrm{Ni}$, but $\mathrm{Na}, \mathrm{K}$, $\mathrm{Zn}$, and $\mathrm{Pb}$ are noticeably enriched in MBM-APCr compared with MBM-BA, reflecting the high volatilities of these elements (Table 1). The concentrations of soluble salts, such as $\mathrm{NaCl}$ (Bogush et al., 2018), and toxic elements, such as $\mathrm{Zn}$ and $\mathrm{Pb}$ in $\mathrm{MBM}-$ APCr, should be considered in making decisions about its treatment and utilisation. Interestingly, although $\mathrm{Na}, \mathrm{K}$, and $\mathrm{Mg}$ are also present in MBM-BA at relatively high concentrations, the XRD analysis did not identify any associated crystalline phases; previous works suggest that they may be found as $\mathrm{KNaCa}_{2}\left(\mathrm{PO}_{4}\right)_{2} / \mathrm{MgCa}_{2}\left(\mathrm{PO}_{4}\right)_{2}$ (Leng et al., 2019a). Also, disodium tricalcium silicate $\left(\mathrm{Na}_{2} \mathrm{Ca}_{3} \mathrm{Si}_{3} \mathrm{O}_{10}\right)$ was previously identified in MBM-BA (Bogush et al., 2018). Low solubilities of $\mathrm{Na}, \mathrm{K}$, and $\mathrm{Mg}$ were observed during water leaching of MBM-BA (Leng et al., 2019a).

\subsection{P removal from wastewater by meat and bone meal ash}

\subsubsection{Effect of contact of time}

As seen in Fig. 2a, P removal by MBM-BA from the synthetic phosphate wastewater increased logarithmically with the contact time until equilibrium was obtained within 
about $30-45 \mathrm{~min}$, which is an equilibration time close to those obtained in previous studies with similar reagents for P removal from wastewaters (Jang and Kang, 2002; N. Vassilev et al., 2013; Yang et al., 2016). The fast removal process indicates that the primary removal mechanism might be chemical precipitation (Lu et al., 2009). Decreasing the particle size of MBM-BA from $>1000 \mu \mathrm{m}$ to $<63 \mu \mathrm{m}$ resulted in a significant $\mathrm{P}$ removal increase from 13.5 to $279 \mathrm{mg} \mathrm{PO}_{4}{ }^{3-} / \mathrm{g}$ ash (Fig. 2a and Table 3). A similar equilibration time was observed for MBM-APCr (Fig. 2b). And smaller particles also removed more phosphate than larger ones. The highest $\mathrm{P}$ removal capacity obtained with MBM-APCr was $36.7 \mathrm{mg} \mathrm{PO}_{4}{ }^{3-} / \mathrm{g}$ ash for the size fraction $<63 \mu \mathrm{m}$, whereas $250-$ $500 \mu \mathrm{m}$ MBM-APCr particles only removed $\sim 13 \mathrm{mg} \mathrm{PO}_{4}{ }^{3-} / \mathrm{g}$ ash (Fig. 2b). Thus, the $\mathrm{P}$ uptakes of MBM-APCr particles were significantly lower than those of MBM-BA with the same size range (Figs. 2a and b). Previous studies have also reported $\mathrm{P}$ removal capacities ranging from lower than 10 to more than $62.3 \mathrm{mg} \mathrm{PO}_{4}{ }^{3-} / \mathrm{g}$ using similar $\mathrm{P}$ removal materials (Table 4). Our previous study reported a P removal capacity of 115 $\mathrm{mg} \mathrm{PO}_{4}{ }^{3-} / \mathrm{g}$ (Leng et al., 2019b), which is higher than the whole sample of MBM-BA (52.9 $\mathrm{mg} \mathrm{PO}{ }_{4}^{3-} / \mathrm{g}$ ash, Table 3). This is because a different source of MBM-BA was used, and the effect of particle size was not considered; plus, the random sampling of MBM-BA with a small sample size resulted in sampling more smaller-size particles in that study. Given that the different fractions were ground to the same particle size for use in wastewater treatment, the increased removal of $\mathrm{P}$ by MBM-BA relative to MBMAPCr particles of the same size also suggests that the $\mathrm{P}$ removal mechanism is precipitation rather than adsorption. In addition, the unground MBM-BA fractions of different sizes have also been tested to have comparable P uptake capacities (Table 3). The chemical differences such as the available quantities of metal ions rather than the size differences led to the considerably different $\mathrm{P}$ removal performance.

It seems likely that the $\mathrm{Ca}(\mathrm{OH})_{2}$, which was not observed in MBM-APCr, but found 
to increase with decreasing MBM-BA particle size (Fig. 1), acted as a source of calcium for precipitation of phosphate (Blanco et al., 2016; Hermassi et al., 2017; Li et al., 2016; Morse et al., 1998). For MBM-BA, the smaller particles removed more $\mathrm{P}$ than did larger ones due to their higher contents of $\mathrm{Ca}(\mathrm{OH})_{2}$. In the presence of $\mathrm{Ca}(\mathrm{OH})_{2}$ and $\mathrm{PO}_{4}{ }^{3-}$, HAP, tricalcium phosphate $\left(\mathrm{Ca}_{3}\left(\mathrm{PO}_{4}\right)_{2}, \alpha / \beta\right)$, and dicalcium phosphate anhydrous $\left(\mathrm{CaHPO}_{4}\right)$ or dicalcium phosphate dihydrate $\left(\mathrm{CaHPO}_{4} \cdot 2 \mathrm{H}_{2} \mathrm{O}\right)$, can be precipitated (Table 2); evidence for their formation is discussed in the following.

\subsubsection{Effect of $\mathrm{pH}$ on $\mathrm{P}$ removal by meat and bone meal bottom ash}

Calcium phosphate precipitation is highly sensitive to $\mathrm{pH}$, and the favourable $\mathrm{pH}$ is generally alkaline. Fig. $2 \mathrm{c}$ shows that a higher equilibrium $\mathrm{pH}(\sim 8$ or higher) promoted the removal of more phosphate from the synthetic wastewater. The selected equilibrium $\mathrm{pH}$ values (corresponding to the acid loads for $\mathrm{pH}$ adjustment shown in Fig. 2d) for maintaining high capacities of MBM-BA with different particle sizes are shown in Table 3 (the circled points in Figs. 2c and d). Equilibrium pH values of 8.0-8.4 achieved high $\mathrm{P}$ removal capacity and met the effluent standard of $\mathrm{pH}$ 6-9. Lower equilibrium $\mathrm{pH}$ values led to a dramatic decrease in removal capacity, and the equilibrium $\mathrm{pH}<7.0$ can result in the leaching of $\mathrm{P}$ (Fig. 2c).

The presence of $\mathrm{PO}_{4}{ }^{3-}$ in the wastewater creates a buffer system (Fig. 3, Eqs. 2-7), and the change in phosphorus speciation as a function of $\mathrm{pH}$ controls the phosphate salts that will precipitate (Gu et al., 2021; Liu et al., 2012). As seen in Fig. 2e, acid neutralisation capacities of MBM-BA without phosphate (control experiments) are higher than those with $300 \mathrm{mg} \mathrm{PO}_{4}{ }^{3-} / \mathrm{L}$ in the wastewater treatment experiments (Fig. 2d). For example, with the same acid load of $6 \mathrm{mM} \mathrm{H}^{+} / \mathrm{g}$ ash, the equilibrium $\mathrm{pH}$ of the former system is $>11.5$ (Fig. 2e), while that of the latter is $<10.0$ (Fig. 2d). Therefore, for the wastewater treatment carried out in the present study, $\mathrm{HPO}_{4}{ }^{2-}$ consumed $\mathrm{OH}^{-}$ (Eq. 2) and produced $\mathrm{PO}_{4}{ }^{3-}$ which can be easily precipitated with $\mathrm{Ca}^{2+}$ to produce 
$\mathrm{Ca}_{5}\left(\mathrm{PO}_{4}\right)_{3}(\mathrm{OH})($ Eq. 3$)$ or $\mathrm{Ca}_{3}\left(\mathrm{PO}_{4}\right)_{2}(\mathrm{Eq} .4)$. It is also possible that $\mathrm{HPO}_{4}{ }^{2-}$ precipitated with $\mathrm{Ca}^{2+}$ to produce $\mathrm{CaHPO}_{4}$ or $\mathrm{CaHPO}_{4} \cdot 2 \mathrm{H}_{2} \mathrm{O}$ (Eq. 5) in the $\mathrm{pH}$ range of 6-9 (Table 2 and Fig. 3). At acidic $\mathrm{pH}, \mathrm{HPO}_{4}{ }^{2-}$ would combine with $\mathrm{H}^{+}$and form $\mathrm{H}_{2} \mathrm{PO}_{4}{ }^{-}$which cannot be easily precipitated as monohydrate/anhydrous monocalcium phosphates $\left(\mathrm{Ca}\left(\mathrm{H}_{2} \mathrm{PO}_{4}\right)_{2} / \mathrm{Ca}\left(\mathrm{H}_{2} \mathrm{PO}_{4}\right)_{2} \cdot \mathrm{H}_{2} \mathrm{O} ; \mathrm{Eq} .7\right)$ because these are highly soluble (Table 2 and Fig. 3). Considering the characteristics, such as $\mathrm{Ca} / \mathrm{P}$ mole ratio and solubility (as indicated by the $\mathrm{K}_{\mathrm{sp}}$ shown in Table 2), of the commonly seen calcium phosphates, the possibilities for the formation of these compounds, if abundant calcium was available at a favourable $\mathrm{pH}$, would be in the sequence of $\mathrm{HAP}>\mathrm{Ca}_{3}\left(\mathrm{PO}_{4}\right)_{2}>$ $\mathrm{CaHPO}_{4} / \mathrm{CaHPO}_{4} \cdot 2 \mathrm{H}_{2} \mathrm{O}>\mathrm{Ca}\left(\mathrm{H}_{2} \mathrm{PO}_{4}\right)_{2} / \mathrm{Ca}\left(\mathrm{H}_{2} \mathrm{PO}_{4}\right)_{2} \cdot \mathrm{H}_{2} \mathrm{O}$.

$$
\begin{aligned}
& \mathrm{HPO}_{4}{ }^{2-}{ }_{(\mathrm{aq})}+\mathrm{OH}^{-}{ }_{(\mathrm{aq})} \rightarrow \mathrm{PO}_{4}{ }^{3-}{ }_{(\mathrm{aq})}+\mathrm{H}_{2} \mathrm{O}_{(\mathrm{aq})} \\
& 3 \mathrm{PO}_{4}{ }^{3-}{ }_{(\mathrm{aq})}+5 \mathrm{Ca}^{2+}{ }_{(\mathrm{aq})}+\mathrm{OH}^{-}{ }_{(\mathrm{aq})} \rightarrow \mathrm{Ca}_{5}\left(\mathrm{PO}_{4}\right)_{3}(\mathrm{OH})_{(\mathrm{s})} \\
& 2 \mathrm{PO}_{4}{ }^{3-}{ }_{(\mathrm{aq})}+3 \mathrm{Ca}^{2+}{ }_{(\mathrm{aq})} \rightarrow \mathrm{Ca}_{3}\left(\mathrm{PO}_{4}\right)_{2(\mathrm{~s})} \\
& 2 \mathrm{HPO}_{4}{ }^{2-}{ }_{(\mathrm{aq})}+\mathrm{Ca}^{2+}{ }_{(\mathrm{aq})}+\left(2 \mathrm{H}_{2} \mathrm{O}\right)_{(\mathrm{aq})} \rightarrow \mathrm{CaHPO}_{4}\left(\mathrm{CaHPO}_{4} \cdot 2 \mathrm{H}_{2} \mathrm{O}\right)_{(\mathrm{s})} \\
& \mathrm{HPO}_{4}{ }^{2-}{ }_{(\mathrm{aq})}+\mathrm{H}^{+}{ }_{(\mathrm{aq})} \rightarrow \mathrm{H}_{2} \mathrm{PO}_{4}^{\left.-{ }_{(a q}\right)} \\
& \mathrm{H}_{2} \mathrm{PO}_{4}{ }_{(\mathrm{aq})}+\mathrm{Ca}^{2+}{ }_{(\mathrm{aq})}+\left(\mathrm{H}_{2} \mathrm{O}\right)_{(\mathrm{aq})} \leftrightarrow \mathrm{Ca}\left(\mathrm{H}_{2} \mathrm{PO}_{4}\right)_{2(\mathrm{aq})}\left[\mathrm{Ca}\left(\mathrm{H}_{2} \mathrm{PO}_{4}\right)_{2} \cdot \mathrm{H}_{2} \mathrm{O}_{(\mathrm{aq}}\right]
\end{aligned}
$$

The calcium release behaviour of MBM-BA (Fig. 4) in the experiments for P removal from wastewater, and control experiments without $\mathrm{P}$, implies a possible phosphate precipitation formation sequence of $\mathrm{HAP}>\mathrm{Ca}_{3}\left(\mathrm{PO}_{4}\right)_{2}>\mathrm{CaHPO}_{4} / \mathrm{CaHPO}_{4} \cdot 2 \mathrm{H}_{2} \mathrm{O}$. Fig. $4 \mathrm{a}$ plots calcium concentrations in the wastewater filtrates after P removal compared to the filtrates for the control batches (Fig. 4a). Almost no calcium was found in the filtrates from $\mathrm{P}$ removal without $\mathrm{pH}$ adjustment, as it was consumed by precipitation with phosphate. It indicates that the calcium released during water leaching (Fig. 4a) was available for precipitation of phosphate in the $\mathrm{P}$ removal experiments, since the $\mathrm{pH}$ was favourable (9.42-11.80, Fig. 4b) and the phosphate concentration was sufficient (initially $300 \mathrm{mg} / \mathrm{L}$ or $3.16 \mathrm{mM} / \mathrm{L}$ ). A lower $\mathrm{pH}$ was measured after wastewater 
treatment than in the control experiments due to the neutralisation effect $\mathrm{HPO}_{4}{ }^{2-}$ dissociation (since $\mathrm{K}_{2} \mathrm{HPO}_{4}$ was used to prepare the synthetic wastewater). Based on Fig. 3 , it can be assumed that the phosphate species in the extracts after wastewater treatment (pH 8.5-11.8, Fig. 4b) were mainly $\mathrm{HPO}_{4}{ }^{2-}$ and $\mathrm{PO}_{4}{ }^{3-}$ (Gu et al., 2021; Liu et al., 2012). Therefore, removal of $\mathrm{P}$ in the form of $\mathrm{PO}_{4}{ }^{3-}$ by the formation of HAP and/or $\mathrm{Ca}_{3}\left(\mathrm{PO}_{4}\right)_{2}$ was favoured over precipitation of $\mathrm{CaHPO}_{4} / \mathrm{CaHPO}_{4} \cdot 2 \mathrm{H}_{2} \mathrm{O}$. Interestingly, a very low calcium release during water leaching of MBM-BA with size $<63 \mu \mathrm{m}$ was observed, which can be attributed to the low solubility of $\mathrm{Ca}(\mathrm{OH})_{2}$ at $\mathrm{pH} \sim 12$.

The $\mathrm{Ca} / \mathrm{P}$ mole ratio in Fig. $4 \mathrm{c}$, the ratio between the calcium released during water/acid leaching in the control experiments, and the $\mathrm{P}$ uptake by MBM-BA during wastewater treatment, suggests the formation of HAP. The mole ratios of $\mathrm{Ca} / \mathrm{P} 1.22-$ 1.73 (except for MBM-BA $<63 \mu \mathrm{m}$, which released insufficient calcium) is inconsistent with formation of $\mathrm{CaHPO}_{4} / \mathrm{CaHPO}_{4} \cdot 2 \mathrm{H}_{2} \mathrm{O}(\mathrm{Ca} / \mathrm{P}$ of 1.0$)$ formation (Fig. $4 \mathrm{c}$ ), but consistent with the formation of $\mathrm{HAP}(\mathrm{Ca} / \mathrm{P}$ of 1.67$)$ and $\mathrm{Ca}_{3}\left(\mathrm{PO}_{4}\right)_{2}(\mathrm{Ca} / \mathrm{P}$ of 1.5$)$. HAP precipitation on MBM-BA seed crystals (Fig. 1a), seems likely, as the HAP seed crystals lower the activation energy for crystallisation of new HAP, as the found for other materials (Jang and Kang, 2002; Molle et al., 2005a; Troesch et al., 2016; N. Vassilev et al., 2013).

XRD analysis of MBM-BA after its use for P removal from the synthetic wastewater confirmed the enrichment of HAP and the disappearance of $\mathrm{Ca}(\mathrm{OH})_{2}$ and $\mathrm{CaCO}_{3}$ (Fig. 5a). Also, FTIR analysis shows the presence of $\mathrm{Ca}(\mathrm{OH})_{2}$ (peak around $3640 \mathrm{~cm}^{-1}$ ) and $\mathrm{CaCO}_{3}$ (peak around $1420 \mathrm{~cm}^{-1}$ ) in MBM-BA, and these components vanished after wastewater treatment (Figs. $5 \mathrm{~b}$ and c). The peak around $1430 \mathrm{~cm}^{-1}$ remaining after wastewater treatment (Fig. 5c) could be the substitution of phosphate ion by $\mathrm{CO}_{3}{ }^{2-}$ in the crystal structure of apatite (Fleet, 2009; Xu et al., 2021). No evidence was found for precipitation of $\mathrm{Ca}_{3}\left(\mathrm{PO}_{4}\right)_{2}$ and $\mathrm{CaHPO}_{4} / \mathrm{CaHPO}_{4} \cdot 2 \mathrm{H}_{2} \mathrm{O}$. 
3.2.3 Content of $\mathrm{P}$ in meat and bone meal ash after wastewater treatment ( $\mathrm{P}$ recovery potential)

The $\mathrm{P}$ contents in MBMA before and after its use for $\mathrm{P}$ removal from the synthetic phosphate wastewater are shown in Figs. 6a and b. The P content of MBM-BA (whole sample) increased from $14.33 \%$ to $16.30 \%$ (Fig. 6a), and that of MBM-BA $<63 \mu \mathrm{m}$ from $7.90 \%$ to $14.94 \%$ (Fig. 6 b). While both the precipitation of phosphate and the mass loss resulting from the leaching of soluble salts contributed to these percentage increases, the former dominated the P content increase of MBM-BA. As seen in Fig. 6c, calcium was the dominant soluble component from MBM-BA water leaching in the control experiment, and $\mathrm{Na}$ and $\mathrm{K}$ presented at very low concentrations, with $\mathrm{Mg}$ and $\mathrm{Li}$ being undetectable. $\mathrm{Na}, \mathrm{K}$, and $\mathrm{Mg}$ may be immobilised as low-soluble phosphates or other low-soluble phases such as silicates/aluminosilicates (Leng et al., 2019a).

On the other hand, the reduction of the solid mass due to the dissolution of soluble salts contributed significantly to the apparent increase of the P content of MBM-APCr. Although MBM-APCr removed much less P from the wastewater than MBM-BA, the P content of MBM-APCr also increased considerably from $9.28 \%$ to $11.20 \%$. As shown in Fig. 6d, Na and K account for more than 3-14\% of the MBM-APCr sample mass. If the anions were taken into consideration, e.g., $\mathrm{Na}^{+}$with $\mathrm{Cl}^{-}$and $\mathrm{K}$ with $\mathrm{SO}_{4}{ }^{2-}$ (according to XRD analysis result), 7-34\% mass loss would be observed, not including other soluble elements. The mass balance calculation (not shown) indicates this is consistent with the observed increase in $\mathrm{P}$ content.

MBM-BA thus has a significant $\mathrm{P}$ content, and became enriched with $\mathrm{P}$ after being used to remove phosphate from wastewater, qualifying it as a "synthetic phosphate rock" for phosphoric acid production. Despite its $\mathrm{P}$ content, $\mathrm{MBM}-\mathrm{APCr}$ is less promising in this application, because of its release of undesirable salt $(\mathrm{Na}, \mathrm{K}, \mathrm{Cl})$ during $\mathrm{P}$ recovery and wastewater treatment. 


\subsection{Recovery of phosphorus by acid dissolution}

MBM-BA before and after its use for $\mathrm{P}$ removal from wastewater was used for $\mathrm{P}$ recovery by $\mathrm{H}_{2} \mathrm{SO}_{4}$ dissolution, and the results are shown in Fig. 7.

The acid consumptions for P recovery from MBM-BA that had not been used for wastewater treatment varied markedly for the different size fractions. An acid load of 12 $\mathrm{mM} \mathrm{H}^{+} / \mathrm{g}$ ash corresponded to only $2.8 \mathrm{mM} \mathrm{H}^{+} / \mathrm{mM}^{\mathrm{P}}$ for the fraction $>1000 \mu \mathrm{m}$, but to $176 \mathrm{mM} \mathrm{H}^{+} / \mathrm{mM} \mathrm{P}$ for the fraction $<63 \mu \mathrm{m}$ (Fig. 7a), due to the acid neutralisation capacity differences between these fractions. The fraction $<63 \mu \mathrm{m}$ had very high alkalinity, so that only $2.7 \%$ of the total P (Fig. 7b) was dissolved at an acid load of 12 $\mathrm{mM} \mathrm{H} / \mathrm{g}$ ash. P recovery from the $63-125 \mu \mathrm{m}$ fraction was also relatively poor, at only $61 \%$. The low recoveries were consistent with the relatively high $\mathrm{pH}$ values of the leachates, 5.1 and 6.7 for the $63-125 \mu \mathrm{m}$ and $<63 \mu \mathrm{m}$ fractions, respectively (Fig. 7c). However, the recovery rate of the whole MBM-BA sample was $77 \%$ (Fig. 7b), since these fractions only accounted for $\sim 10 \%$ of MBM-BA (Table 1). Because of the high P content of MBM-BA (14.33\%, Table 1), an acid consumption of $3.35 \mathrm{mM} \mathrm{H}+\mathrm{mM} \mathrm{P}$ was obtained, which is a value similar to those obtained in previous studies from the acid dissolution of MBMA (Leng et al., 2019a), animal manures or their ashes (Cohen, 2009; Ekpo et al., 2016), and sewage sludge ashes (Petzet et al., 2012).

The recovery rate for $\mathrm{P}$ from MBM-BA after it was used for the treatment of phosphate wastewater was $84 \%$ with an acid consumption of $2.7 \mathrm{mM} \mathrm{H}^{+} / \mathrm{mM} \mathrm{P}(2.6-3.0$ $\mathrm{mM} \mathrm{H} / \mathrm{mM} P$ for different fractions), which were higher than that of MBM-BA (Figs. $7 \mathrm{a}$ and $\mathrm{b}$ ). The higher recovery rate and lower acid consumption are because (i) the $\mathrm{P}$ content in MBM-BA after wastewater treatment was higher than MBM-BA; and (ii) the alkalinity of MBM-BA had been reduced during wastewater treatment (see Table 1 and Fig. 4). The acid consumption saved for an equal amount of $\mathrm{P}$ was $19 \%$ (6.6\%-98\% for different fractions) (Fig. 7a). Further increasing the acid load to $16 \mathrm{mM} \mathrm{H}^{+} / \mathrm{g}$ ash led to 
an almost full recovery (P recovery rate $\sim 100 \%$ ), but at the expense of higher acid consumptions per unit of $\mathrm{P}$ (Fig. 7d).

\subsection{Implications}

(1) MBMA is a valuable "synthetic phosphate rock", from which P can be recovered. It represents an alternative to imported natural phosphate rock, particularly in places such as the UK and EU, with a scarcity of phosphorus mines. Compared with the acid dissolution of natural phosphate rock $\left[\mathrm{Ca}_{5}\left(\mathrm{PO}_{4}\right)_{3}(\mathrm{~F}, \mathrm{OH})\right]$ (Eqs. 8-11), which has a stoichiometric acid consumption of $3.33 \mathrm{~mol} \mathrm{H} \mathrm{H}^{+} / \mathrm{mol} \mathrm{H}_{3} \mathrm{PO}_{4}\left(1.67 \mathrm{~mol} \mathrm{H}_{2} \mathrm{SO}_{4} / \mathrm{mol}\right.$ $\mathrm{H}_{3} \mathrm{PO}_{4}$ ) or $2.33 \mathrm{~mol} \mathrm{H}^{+} / \mathrm{mol} \mathrm{H}_{2} \mathrm{PO}_{4}^{-}$, the acid consumptions for MBM-BA before (whole sample: $3.4 \mathrm{mM} \mathrm{H} / \mathrm{mM} \mathrm{P}$ ) and after wastewater treatment (whole sample: $2.7 \mathrm{mM}$

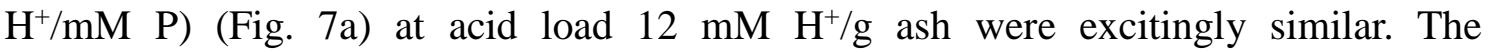
dissolution of HAP at this acid load was not complete, meaning the reaction of Eq. 11 was only partially accomplished. This is consistent with the leachate $\mathrm{pH}$ (2.5-2.7) (Fig. 7c), which is a $\mathrm{pH}$ range dominated by $\mathrm{H}_{2} \mathrm{PO}_{4}^{-}$(Fig. 3). A higher acid load (16 $\mathrm{mM} \mathrm{H}^{+} / \mathrm{g}$ ash) promoted the completion of Eq. 11, and acid consumptions of 3.1-3.4 $\mathrm{mM} \mathrm{H} \mathrm{H}^{+} / \mathrm{mM}$ P were observed (Fig. 7d) with a final leachate $\mathrm{pH} \sim 2.0$ (not shown).

$2 \mathrm{Ca}_{5}\left(\mathrm{PO}_{4}\right)_{3}(\mathrm{~F}, \mathrm{OH})_{(\mathrm{s})}+2 \mathrm{H}^{+}{ }_{(\mathrm{aq})}+\mathrm{SO}_{4}{ }^{2-}{ }_{(\mathrm{aq})} \rightarrow 3 \mathrm{Ca}_{3}\left(\mathrm{PO}_{4}\right)_{2}+\mathrm{CaSO}_{4(\mathrm{~s})}+2 \mathrm{HF}_{(\mathrm{g})}, \mathrm{H}_{2} \mathrm{O}_{(\mathrm{aq})}$

$$
\begin{aligned}
& 3 \mathrm{Ca}_{3}\left(\mathrm{PO}_{4}\right)_{2(\mathrm{~s})}+6 \mathrm{H}^{+}{ }_{(\mathrm{aq})}+3 \mathrm{SO}_{4}{ }^{2-}{ }_{(\mathrm{aq})} \rightarrow 6 \mathrm{CaHPO}_{4(\mathrm{~s})}+3 \mathrm{CaSO}_{4(\mathrm{~s})} \\
& 6 \mathrm{CaHPO}_{4(\mathrm{~s})}+6 \mathrm{H}^{+}{ }_{(\mathrm{aq})}+3 \mathrm{SO}_{4}{ }^{2-}{ }_{(\mathrm{aq})} \rightarrow 6 \mathrm{H}_{2} \mathrm{PO}_{4}{ }_{(\mathrm{aq})}+3 \mathrm{Ca}^{2+}{ }_{(\mathrm{aq})}+3 \mathrm{CaSO}_{4(\mathrm{~s})} \\
& 6 \mathrm{H}_{2} \mathrm{PO}_{4}{ }_{(\mathrm{aq})}+6 \mathrm{H}^{+}{ }_{(\mathrm{aq})}+3 \mathrm{Ca}^{2+}{ }_{(\mathrm{aq})}+3 \mathrm{SO}_{4}{ }^{2-}{ }_{(\mathrm{aq})} \rightarrow 6 \mathrm{H}_{3} \mathrm{PO}_{4(\mathrm{aq})}+3 \mathrm{CaSO}_{4(\mathrm{~s})}
\end{aligned}
$$

(2) There are significant differences between MBM-BA and MBM-APCr, and they should be managed and used separately. MBM-APCr may not be suitable for use directly for phosphate wastewater treatment or phosphorus recovery because it releases alkaline salts such as $\mathrm{NaCl}$. Pretreatment to wash out the salts could facilitate its subsequent utilisation, as was suggested in ref. (Bogush et al., 2018). The MBM-BA 
may be used directly as a raw material for P recovery, but it would be preferable to use it for phosphate removal from wastewater to increase the $\mathrm{P}$ content and decrease the alkalinity before $\mathrm{P}$ recovery.

(3) Different MBM-BA particle size fractions could also be managed and used separately. $\mathrm{P}$ could be recovered by acid dissolution of the larger fractions (e.g., $\geq 250$ $\mu \mathrm{m}$ ), which account for $\sim 80$ wt. $\%$ of MBM-BA and have a high P content, since their relatively low $\mathrm{Ca}(\mathrm{OH})_{2}$ contents make them less useful for removal $\mathrm{P}$ from wastewater. On the other hand, the smaller particles have a relatively low $\mathrm{P}$ content, but with high $\mathrm{Ca}(\mathrm{OH})_{2}$, which makes them useful for $\mathrm{P}$ removal. They can be used as a valuable reagent for the removal and recovery of $\mathrm{P}$ from wastewater. Taking abattoir wastewater as an example, the $\sim 6 \times 10^{8} \mathrm{~m}^{3} / \mathrm{y}$ generated in Europe with a nominal $\mathrm{P}$ concentration of $10 \mathrm{mg} / \mathrm{L}$ (or $30 \mathrm{mg} \mathrm{PO}_{4}{ }^{3-} / \mathrm{L}$ ) represents $1.8 \times 10^{7} \mathrm{~kg} \mathrm{PO}_{4}{ }^{3-} / \mathrm{y}$ (Mittal, 2004; Pol Marquer et al., 2019). This figure balances reasonably well with a phosphate removal potential of $1.2 \times 10^{7} \mathrm{~kg} \mathrm{PO}_{4}^{3-} / \mathrm{y}$ represented by European MBM-BA arisings of $\sim 3.0 \times 10^{8} \mathrm{~kg} / \mathrm{y}$ (EFPRA, 2019) (assuming that BA represents $~ 85 \%$ of MBMA), of which $20 \%$ is $<250$ $\mu \mathrm{m}$ and has a $\mathrm{PO}_{4}{ }^{3-}$ removal capacity of $\sim 200 \mathrm{mg} \mathrm{PO}_{4}{ }^{3-} / \mathrm{g}$ MBM-BA. Utilising MBMBA in the same industry in this way may have logistical advantages, or there may be a wider potential for a circular economy approach for MBM-BA management. It could be used for the treatment of industrial wastewaters with high P concentrations. In all cases, the $\mathrm{pH}$ would need careful monitoring and adjustment to obtain satisfactory $\mathrm{P}$ removal efficiency at no risk of $\mathrm{P}$ release.

(4) Although the previous study showed that the minor elements in MBM-BA such as $\mathrm{Zn}, \mathrm{Cu}, \mathrm{Pb}, \mathrm{Cr}, \mathrm{Mn}$, and $\mathrm{Ni}$ were barely leachable at mild acid to alkaline $\mathrm{pH}$, e.g., $\mathrm{Cu}$ and $\mathrm{Zn}$ mainly started to leach at $\mathrm{pH}<4$ (Leng et al., 2019a). The enrichment of these elements, especially the $\mathrm{Zn}$ and $\mathrm{Pb}$ in MBM-BA with particle size $<250 \mu \mathrm{m}$ (Table 1) and MBM-APCr, implies potential secondary environmental pollution when the ashes 
are utilised for wastewater remediation. The hazard posed by these elements in the low pH MBMA residue post P-recovery may need more investigation. In the real-world application of MBM-BA, trace elements should be measured to determine the associated risk on a case-by-case basis.

\section{Conclusions}

MBM-BA and MBM-APCr were composed of particles with different size distributions, and were dominated by fractions with particle size larger than $250 \mu \mathrm{m}$ $(\sim 80 \%)$ and fractions smaller than $500 \mu \mathrm{m}(100 \%)$. The $\mathrm{P}$ content in MBM-BA (14.33\%) was higher than MBM-APCr (9.28\%); the larger the size of ash, the higher the P content. The mineral composition of MBM-BA was dominated by HAP, whereas that of MBM-APCr was dominated by $\mathrm{NaCl}$ and aphthitalite.

$\mathrm{P}$ uptake capacities of $13.5-279 \mathrm{mg} \mathrm{PO}_{4}{ }^{3-} / \mathrm{g}$ ash from synthetic phosphate wastewater were achieved by MBM-BA; the smaller the size, the higher the uptake capacities. The $\mathrm{P}$ removal mechanism was shown to be HAP crystallisation/precipitation. $\mathrm{P}$ uptake capacities of $13.5-36.6 \mathrm{mg} \mathrm{PO}_{4}{ }^{3-} / \mathrm{g}$ ash were obtained using MBM-APCr.

The P content of MBM-BA was increased from $14.33 \%$ to $16.30 \%$ using it to remove $\mathrm{P}$ from the wastewater. Its $\mathrm{P}$ enrichment reduced the acid consumption during acid dissolution from 3.4 to $2.7 \mathrm{mM} \mathrm{H} / \mathrm{mM}$, with the recovery of $\sim 84 \%$ of the P. Use of MBM-BA to treat P-containing wastewater such as abattoir wastewater, with subsequent $\mathrm{P}$ recovery by acid dissolution can be a promising circular economy approach for MBM-BA management.

\section{Acknowledgments}

This research was supported by the National Natural Science Foundation of China (No. 51808278), the British Council (Newton fund), and the China Scholarship Council 
[File No. 201503780024].

\section{References}

Ali, I., Gupta, V.K., 2006. Advances in water treatment by adsorption technology. Nat. Protoc. 1, 2661-2667. https://doi.org/10.1038/nprot.2006.370

Anonymous Critical Raw Materials [WWW Document], 2014. . Available online. URL https://eur-lex.europa.eu/legal-content/EN/TXT/?uri=CELEX:52014DC0297 (accessed 3.10.18).

Arvanitoyannis, I.S., Ladas, D., 2008. Meat waste treatment methods and potential uses. Int. J. Food Sci. Technol. 43, 543-559. https://doi.org/10.1111/j.13652621.2006.01492.x

Blanco, I., Molle, P., Sáenz de Miera, L.E., Ansola, G., 2016. Basic Oxygen Furnace steel slag aggregates for phosphorus treatment: Evaluation of its potential use as a substrate in constructed wetlands. Water Res. 89, 355-365. https://doi.org/10.1016/j.watres.2015.11.064

Bogush, A.A., Stegemann, J.A., Williams, R., Wood, I.G., 2018. Element speciation in UK biomass power plant residues based on composition, mineralogy, microstructure and leaching. Fuel 211, 712-725. https://doi.org/10.1016/j.fuel.2017.09.103

Cascarosa, E., Gea, G., Arauzo, J., 2012. Thermochemical processing of meat and bone meal: A review. Renew. Sustain. Energy Rev. 16, 942-957. https://doi.org/10.1016/j.rser.2011.09.015

Chen, M., Zeng, G., Zhang, J., Xu, P., Chen, A., Lu, L., 2015. Global Landscape of Total Organic Carbon, Nitrogen and Phosphorus in Lake Water. Sci. Rep. 5, 15043. https://doi.org/10.1038/srep15043

Chi, R., Xiao, C., Gao, H., 2006. Bioleaching of phosphorus from rock phosphate containing pyrites by Acidithiobacillus ferrooxidans. Miner. Eng. 19, 979-981. https://doi.org/10.1016/j.mineng.2005.10.003

Chow, L.C., 2001. Solubility of Calcium Phosphates. Octacalcium Phosphate 1, 94-111. https://doi.org/10.1159/000061650

Cohen, Y., 2009. Phosphorus dissolution from ash of incinerated sewage sludge and animal carcasses using sulphuric acid. Environ. Technol. 30, 1215-1226. https://doi.org/10.1080/09593330903213879

Conley, D.J., Paerl, H.W., Howarth, R.W., Boesch, D.F., Seitzinger, S.P., Havens, K.E., Lancelot, C., Likens, G.E., 2009. ECOLOGY: Controlling Eutrophication: Nitrogen and Phosphorus. Science (80-. ). 323, 1014-1015. https://doi.org/10.1126/science.1167755

Cordell, D., 2010. The story of phosphorus: Sustainability implications of global phosphorus scarcity for food security. Linköping University.

Cordell, D., Drangert, J.O., White, S., 2009. The story of phosphorus: Global food security and food for thought. Glob. Environ. Chang. 19, 292-305. https://doi.org/10.1016/j.gloenvcha.2008.10.009

Coutand, M., Cyr, M., Deydier, E., Guilet, R., Clastres, P., 2008. Characteristics of industrial and laboratory meat and bone meal ashes and their potential applications. J. Hazard. Mater. 150, 522-532. https://doi.org/10.1016/j.jhazmat.2007.04.133

Deydier, E., Guilet, R., Sarda, S., Sharrock, P., 2005. Physical and chemical characterisation of crude meat and bone meal combustion residue: "Waste or raw material?" J. Hazard. Mater. 121, 141-148. https://doi.org/10.1016/j.jhazmat.2005.02.003 
EFPRA, 2019. EFPRA urges commission on shipping of Category 1 material [WWW Document]. URL https://efpra.eu/efpra-urges-commission-allow-shippingcategory-1/

Ekpo, U., Ross, A.B., Camargo-Valero, M.A., Fletcher, L.A., 2016. Influence of pH on hydrothermal treatment of swine manure: Impact on extraction of nitrogen and phosphorus in process water. Bioresour. Technol. 214, 637-644.

https://doi.org/10.1016/j.biortech.2016.05.012

Elser, J., Bennett, E., 2011. Phosphorus cycle: A broken biogeochemical cycle. Nature 478, 29-31. https://doi.org/10.1038/478029a

Fleet, M.E., 2009. Infrared spectra of carbonate apatites: v2-Region bands. Biomaterials 30, 1473-1481. https://doi.org/10.1016/j.biomaterials.2008.12.007

Ghaneian, M.T., Ghanizadeh, G., Alizadeh, M.T.H., Ehrampoush, M.H., Said, F.M., 2014. Equilibrium and kinetics of phosphorous adsorption onto bone charcoal from aqueous solution. Environ. Technol. (United Kingdom) 35, 882-890. https://doi.org/10.1080/09593330.2013.854838

Grzmil, B., Wronkowski, J., 2006. Removal of phosphates and fluorides from industrial wastewater. Desalination 189, 261-268. https://doi.org/10.1016/j.desal.2005.07.008

Gu, S., Fu, B., Ahn, J.W., Fang, B., 2021. Mechanism for phosphorus removal from wastewater with fly ash of municipal solid waste incineration, Seoul, Korea. J. Clean. Prod. 280, 124430. https://doi.org/10.1016/j.jclepro.2020.124430

Harouiya, N., Prost-Boucle, S., Morlay, C., Esser, D., Ruel, S.M., Molle, P., 2011. Performance evaluation of phosphorus removal by apatite in constructed wetlands treating domestic wastewater: Column and pilot experiments. Int. J. Environ. Anal. Chem. 91, 740-752. https://doi.org/10.1080/03067319.2010.520132

Hermassi, M., Valderrama, C., Moreno, N., Font, O., Querol, X., Batis, N.H., Cortina, J.L., 2017. Fly ash as reactive sorbent for phosphate removal from treated waste water as a potential slow release fertilizer. J. Environ. Chem. Eng. 5, 160-169. https://doi.org/10.1016/j.jece.2016.11.027

Hukari, S., Hermann, L., Nättorp, A., 2016. From wastewater to fertilisers - Technical overview and critical review of European legislation governing phosphorus recycling. Sci. Total Environ. 542, 1127-1135. https://doi.org/10.1016/j.scitotenv.2015.09.064

IFDC, 2010. World Phosphate Rock Reserves and Resources. International Fertilizer Development Centre.

Jang, H., Kang, S.H., 2002. Phosphorus removal using cow bone in hydroxyapatite crystallization. Water Res. 36, 1324-1330. https://doi.org/10.1016/S00431354(01)00329-3

Leng, L., Bogush, A.A., Roy, A., Stegemann, J.A., 2019a. Characterisation of ashes from waste biomass power plants and phosphorus recovery. Sci. Total Environ. 690, 573-583. https://doi.org/10.1016/j.scitotenv.2019.06.312

Leng, L., Leng, S., Chen, J., Yuan, X., Li, J., Li, K., Wang, Y., Zhou, W., 2018a. The migration and transformation behavior of heavy metals during co-liquefaction of municipal sewage sludge and lignocellulosic biomass. Bioresour. Technol. 259, 156-163. https://doi.org/10.1016/j.biortech.2018.03.019

Leng, L., Li, H., Yuan, X., Zhou, W., Huang, H., 2018b. Bio-oil upgrading by emulsification/microemulsification: A review. Energy 161, 214-232. https://doi.org/10.1016/j.energy.2018.07.117

Leng, L., Li, J., Wen, Z., Zhou, W., 2018c. Use of microalgae to recycle nutrients in aqueous phase derived from hydrothermal liquefaction process. Bioresour. Technol. 256, 529-542. https://doi.org/10.1016/j.biortech.2018.01.121

Leng, L., Zhang, J., Xu, S., Xiong, Q., Xu, X., Li, J., Huang, H., 2019b. Meat \& bone 
meal (MBM) incineration ash for phosphate removal from wastewater and afterward phosphorus recovery. J. Clean. Prod. 238, 117960.

https://doi.org/10.1016/j.jclepro.2019.117960

Leng, L., Zhang, W., Peng, H., Li, H., Jiang, S., Huang, H., 2020. Nitrogen in bio-oil produced from hydrothermal liquefaction of biomass: A review. Chem. Eng. J. 401, 126030. https://doi.org/10.1016/j.cej.2020.126030

Li, M., Liu, J., Xu, Y., Qian, G., 2016. Phosphate adsorption on metal oxides and metal hydroxides: A comparative review. Environ. Rev. 24, 319-332. https://doi.org/10.1139/er-2015-0080

Li, R., Wang, J.J., Zhou, B., Zhang, Z., Liu, S., Lei, S., Xiao, R., 2017. Simultaneous capture removal of phosphate, ammonium and organic substances by $\mathrm{MgO}$ impregnated biochar and its potential use in swine wastewater treatment. J. Clean. Prod. 147, 96-107. https://doi.org/10.1016/j.jclepro.2017.01.069

Li, W.-W., Yu, H., Rittmann, B.E., 2015. Reuse water pollutants. Nature 528, 29-31.

Liang, Y., Cao, X., Zhao, L., Xu, X., Harris, W., 2014. Phosphorus Release from Dairy Manure, the Manure-Derived Biochar, and Their Amended Soil: Effects of Phosphorus Nature and Soil Property. J. Environ. Qual. 43, 1504-1509. https://doi.org/10.2134/jeq2014.01.0021

Liu, Y., Sheng, X., Dong, Y., Ma, Y., 2012. Removal of high-concentration phosphate by calcite: Effect of sulfate and $\mathrm{pH}$. Desalination 289, 66-71. https://doi.org/10.1016/j.desal.2012.01.011

Lu, S.G., Bai, S.Q., Zhu, L., Shan, H.D., 2009. Removal mechanism of phosphate from aqueous solution by fly ash. J. Hazard. Mater. 161, 95-101. https://doi.org/10.1016/j.jhazmat.2008.02.123

MacDonald, G.K., Bennett, E.M., Potter, P.A., Ramankutty, N., 2011. Agronomic phosphorus imbalances across the world's croplands. Proc. Natl. Acad. Sci. U. S. A. 108, 3086-91. https://doi.org/10.1073/pnas.1010808108

Markou, G., Mitrogiannis, D., Inglezakis, V., Muylaert, K., Koukouzas, N., Tsoukalas, N., Kamitsos, E., Palles, D., Baziotis, I., 2018. Ca(OH)2 Pre-Treated Bentonite for Phosphorus Removal and Recovery From Synthetic and Real Wastewater. Clean Soil, Air, Water 46. https://doi.org/10.1002/clen.201700378

Mayer, B.K., Baker, L.A., Boyer, T.H., Drechsel, P., Gifford, M., Hanjra, M.A., Parameswaran, P., Stoltzfus, J., Westerhoff, P., Rittmann, B.E., 2016. Total Value of Phosphorus Recovery. Environ. Sci. Technol. 50, 6606-6620. https://doi.org/10.1021/acs.est.6b01239

Mazloomi, S., Yousefi, M., Nourmoradi, H., Shams, M., 2019. Evaluation of phosphate removal from aqueous solution using metal organic framework; Isotherm, kinetic and thermodynamic study. J. Environ. Heal. Sci. Eng. 17, 209-218. https://doi.org/10.1007/s40201-019-00341-6

Mittal, G.S., 2004. Characterization of the effluent wastewater from abattoirs for land application. Food Rev. Int. 20, 229-256. https://doi.org/10.1081/FRI-200029422

Molle, P., Liénard, A., Grasmick, A., Iwema, A., Kabbabi, A., 2005a. Apatite as an interesting seed to remove phosphorus from wastewater in constructed wetlands. Water Sci. Technol. 51, 193-203.

Molle, P., Liénard, A., Grasmick, A., Iwema, A., Kabbabi, A., 2005b. Apatite as an interesting seed to remove phosphorus from wastewater in constructed wetlands. Water Sci. Technol. 51, 193-203. https://doi.org/10.2166/wst.2005.0318

Morse, G.K., Brett, S.W., Guy, J.A., Lester, J.N., 1998. Review: Phosphorus removal and recovery technologies. Sci. Total Environ. 212, 69-81. https://doi.org/10.1016/S0048-9697(97)00332-X

Murphy, J., Riley, J.P., 1962. A modified single solution method for the determination of phosphate in natural waters. Anal. Chim. Acta 27, 31-36. 
https://doi.org/10.1016/S0003-2670(00)88444-5

Niu, Y., Tan, H., Hui, S., 2016. Ash-related issues during biomass combustion: Alkaliinduced slagging, silicate melt-induced slagging (ash fusion), agglomeration, corrosion, ash utilization, and related countermeasures. Prog. Energy Combust. Sci. 52, 1-61. https://doi.org/10.1016/j.pecs.2015.09.003

Petzet, S., Peplinski, B., Cornel, P., 2012. On wet chemical phosphorus recovery from sewage sludge ash by acidic or alkaline leaching and an optimized combination of both. Water Res. 46, 3769-3780. https://doi.org/10.1016/j.watres.2012.03.068

Pol Marquer, Rabade, T., Forti, R., 2019. Archive: Meat production statistics [WWW Document]. URL https://ec.europa.eu/eurostat/statisticsexplained/index.php?title=Archive:Meat_production_statistics

Rashidi, N.A., Yusup, S., 2016. Overview on the Potential of Coal-Based Bottom Ash as Low-Cost Adsorbents. ACS Sustain. Chem. Eng. 4, 1870-1884. https://doi.org/10.1021/acssuschemeng.5b01437

Rey, C., Combes, C., Drouet, C., Glimcher, M.J., 2009. Bone mineral: Update on chemical composition and structure. Osteoporos. Int. 20, 1013-1021. https://doi.org/10.1007/s00198-009-0860-y

Sattari, S.Z., Bouwman, A.F., Giller, K.E., van Ittersum, M.K., 2012. Residual soil phosphorus as the missing piece in the global phosphorus crisis puzzle. Proc. Natl. Acad. Sci. U. S. A. 109, 6348-53. https://doi.org/10.1073/pnas.1113675109

Shepherd, J.G., Joseph, S., Sohi, S.P., Heal, K. V., 2017. Biochar and enhanced phosphate capture: Mapping mechanisms to functional properties. Chemosphere 179, 57-74. https://doi.org/10.1016/j.chemosphere.2017.02.123

Tilman, D., Fargione, J., Wolff, B., D’Antonio, C., Dobson, A., Howarth, R., Schindler, D., Schlesinger, W.H., Simberloff, D., Swackhamer, D., 2001. Forecasting agriculturally driven global environmental change. Science 292, 281-284. https://doi.org/10.1126/science.1057544

Tilman, D., Lehman, C., 1987. Human-caused environmental change : Impacts on plant diversity and evolution. Proc. Natl. Acad. Sci. U. S. A. 98, 5433-5440. https://doi.org/10.1073/pnas.091093198

Tõnsuaadu, K., Gross, K.A., Pluduma, L., Veiderma, M., 2012. A review on the thermal stability of calcium apatites. J. Therm. Anal. Calorim. 110, 647-659. https://doi.org/10.1007/s10973-011-1877-y

Troesch, S., Esser, D., Molle, P., 2016. Natural Rock Phosphate: A Sustainable Solution for Phosphorous Removal from Wastewater. Procedia Eng. 138, 119-126. https://doi.org/10.1016/j.proeng.2016.02.069

van Loosdrecht, M.C.M., Brdjanovic, D., 2014. Anticipating the next century of wastewater treatment. Science (80-. ). 344, 1452-1453. https://doi.org/10.1126/science.1255183

Vassilev, N., Martos, E., Mendes, G., Martos, V., Vassileva, M., 2013. Biochar of animal origin: A sustainable solution to the global problem of high-grade rock phosphate scarcity? J. Sci. Food Agric. 93, 1799-1804. https://doi.org/10.1002/jsfa.6130

Vassilev, S. V., Baxter, D., Andersen, L.K., Vassileva, C.G., 2013a. An overview of the composition and application of biomass ash. Part 1. Phase-mineral and chemical composition and classification. Fuel 105, 40-76. https://doi.org/10.1016/j.fuel.2012.09.041

Vassilev, S. V., Baxter, D., Andersen, L.K., Vassileva, C.G., 2013b. An overview of the composition and application of biomass ash.: Part 2. Potential utilisation, technological and ecological advantages and challenges. Fuel 105, 19-39. https://doi.org/10.1016/j.fuel.2012.10.001

Wiśniowska, E., Grobelak, A., Kokot, P., Kacprzak, M., 2019. Sludge legislation- 
comparison between different countries, in: Industrial and Municipal Sludge. Elsevier, pp. 201-224. https://doi.org/10.1016/B978-0-12-815907-1.00010-6

Xu, S., Chen, J., Peng, H., Leng, S., Li, Hui, Qu, W., Hu, Y., Li, Hailong, Jiang, S., Zhou, W., Leng, L., 2021. Effect of biomass type and pyrolysis temperature on nitrogen in biochar, and the comparison with hydrochar. Fuel 291, 120128. https://doi.org/10.1016/j.fuel.2021.120128

Yang, S., Jin, P., Wang, X., Zhang, Q., Chen, X., 2016. Phosphate recovery through adsorption assisted precipitation using novel precipitation material developed from building waste: Behavior and mechanism. Chem. Eng. J. 292, 246-254. https://doi.org/10.1016/j.cej.2016.02.006

Yousefi, M., Nabizadeh, R., Alimohammadi, M., Mohammadi, A.A., Mahvi, A.H., 2019. Removal of phosphate from aqueous solutions using granular ferric hydroxide process optimization by response surface methodology. Desalin. Water Treat. 158, 290-300. https://doi.org/10.5004/dwt.2019.24281 

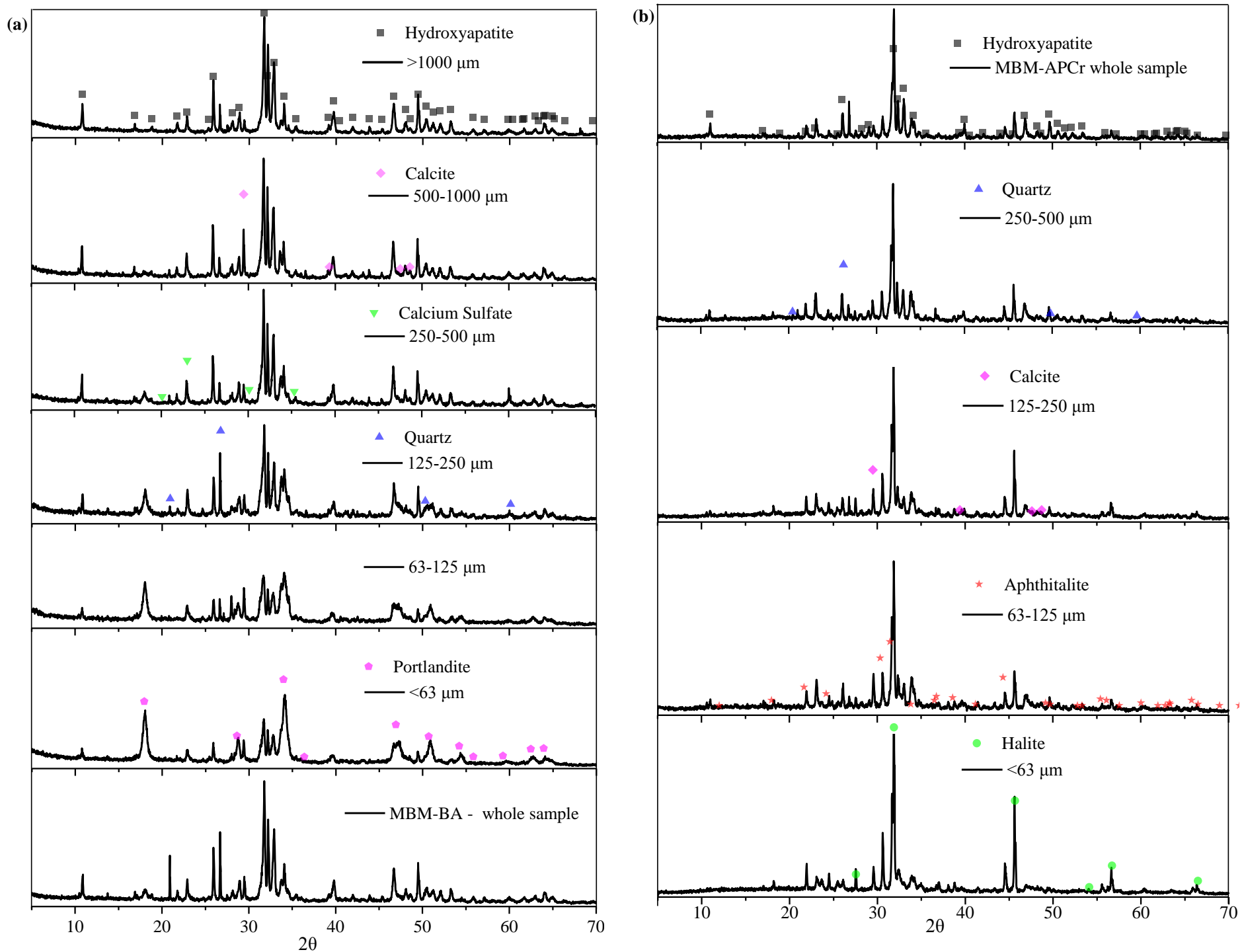

Fig. 1 X-ray powder diffraction (XRD) analysis of meat and bone meal bottom ash (MBM-BA) (a) and air pollution control residue (MBM-APCr) (b). 

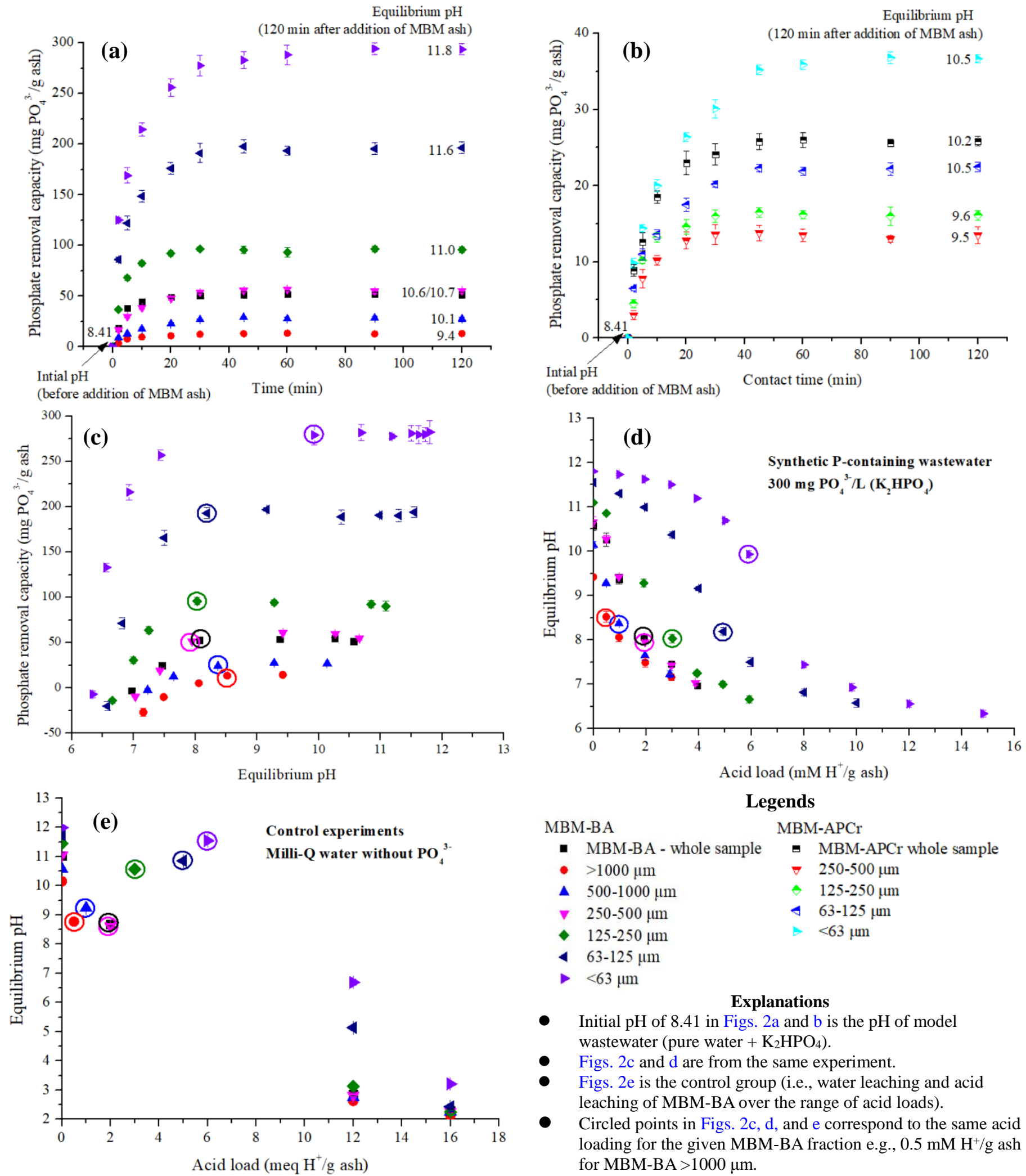

\section{Legends}

MBM-BA

MBM-APCr

- MBM-BA - whole sample

- MBM-APCr whole sample

- $>1000 \mu \mathrm{m}$

$\nabla \quad 250-500 \mu \mathrm{m}$

\ $500-1000 \mu \mathrm{m}$

$\Rightarrow 125-250 \mu \mathrm{m}$

จ $250-500 \mu \mathrm{m}$

- 125-250 $\mathrm{m}$

$\varangle \quad 63-125 \mu \mathrm{m}$

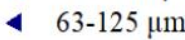

- $<63 \mu \mathrm{m}$

\section{Explanations}

- Initial pH of 8.41 in Figs. 2a and b is the pH of model wastewater (pure water $+\mathrm{K}_{2} \mathrm{HPO}_{4}$ ).

- Figs. $2 \mathrm{c}$ and d are from the same experiment.

- Figs. $2 \mathrm{e}$ is the control group (i.e., water leaching and acid leaching of MBM-BA over the range of acid loads).

- Circled points in Figs. 2c, d, and e correspond to the same acid loading for the given MBM-BA fraction e.g., $0.5 \mathrm{mM} \mathrm{H}^{+} / \mathrm{g}$ ash for MBM-BA $>1000 \mu \mathrm{m}$.

Fig. 2 Effect of contact time on P removal from wastewater by meat and bone meal bottom ash (MBM-BA) (a) and air pollution control residue (MBM-APCr) (b); and the effect of equilibrium $\mathrm{pH}$ on $\mathrm{P}$ removal c); acid load $v s$. equilibrium $\mathrm{pH}$ after wastewater treatment (acid neutralisation capacity of MBM-BA in the presence of phosphate) (d); and the equilibrium $\mathrm{pH}$ of controls without the addition of phosphate (acid neutralisation capacity of MBM-BA in the absence of phosphate) (e). 


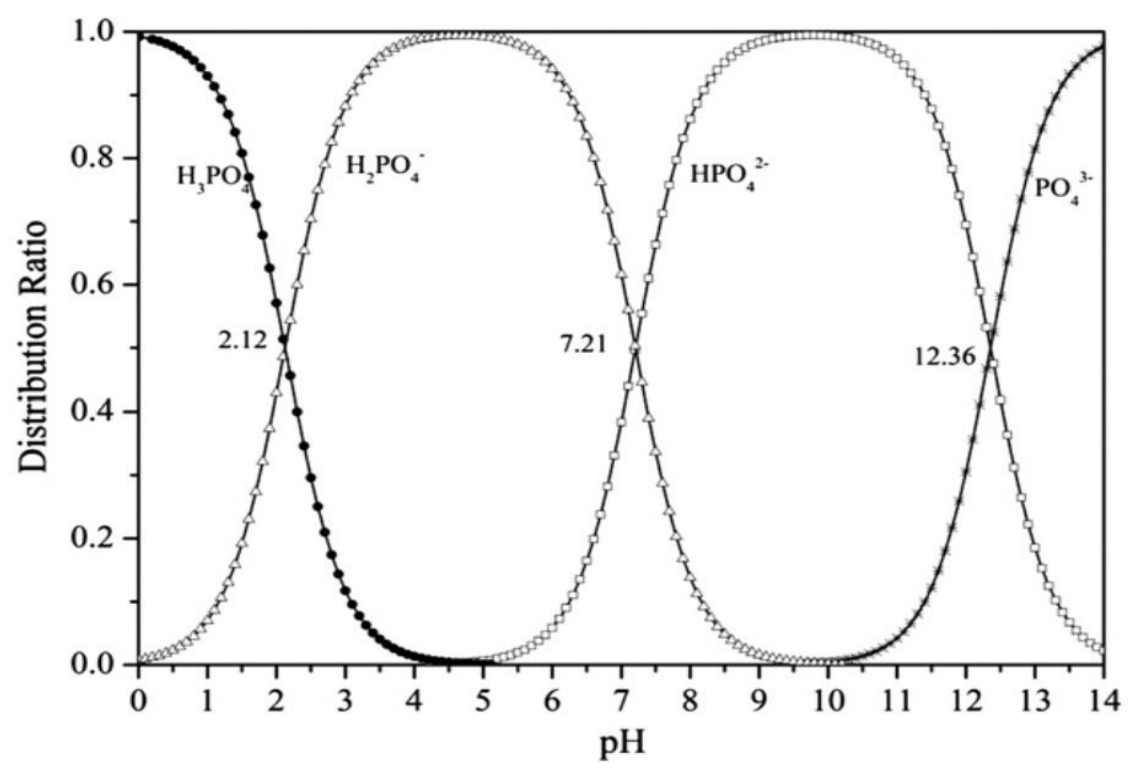

Fig. 3 Phosphate species dissociation equilibrium in different pH (Liu et al., 2012). 


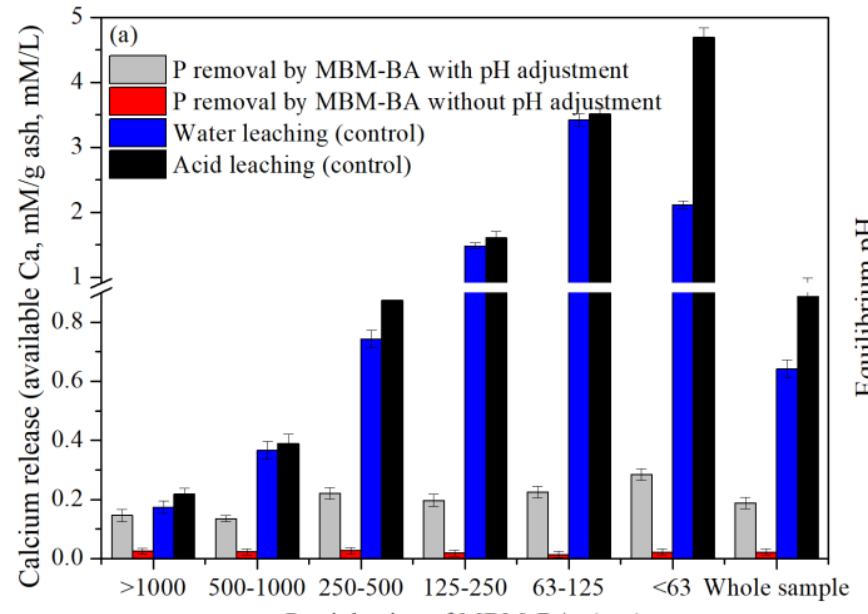

Particle size of MBM-BA $(\mu \mathrm{m})$

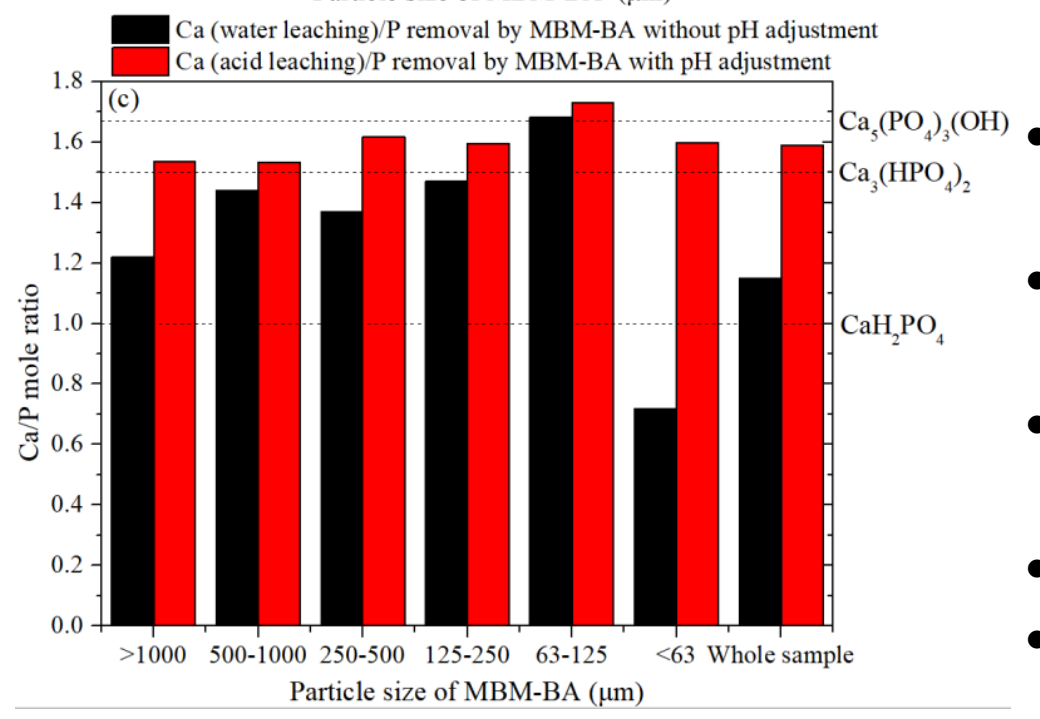

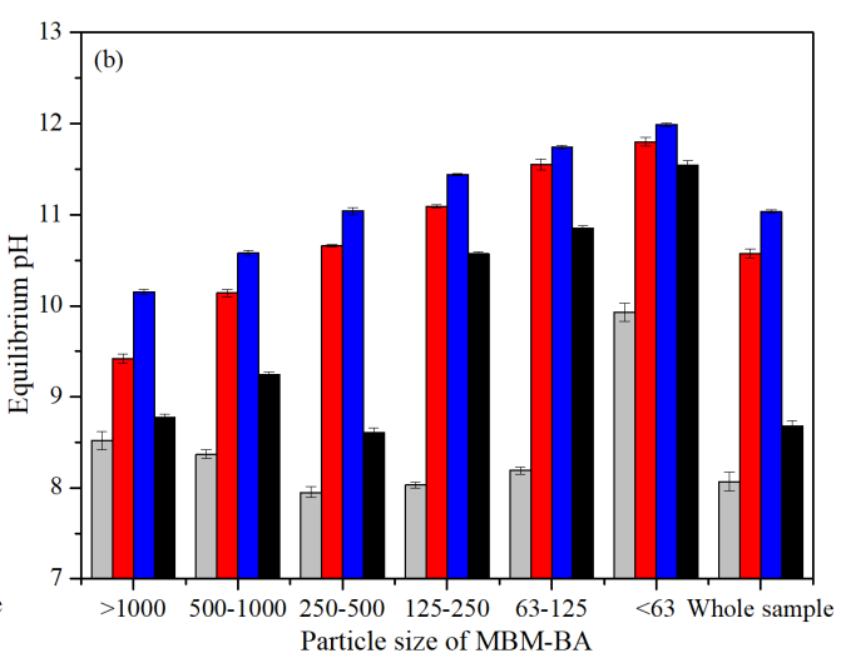

\section{Explanations}

P removal by MBM-BA with $\mathrm{pH}$ adjustment (circled points in Figs. 2c and d with equilibrium $\mathrm{pH}$ and acid load in Table 3 ): $\mathrm{MBM}-\mathrm{BA}+\mathrm{K}_{2} \mathrm{HPO}_{4}+\mathrm{HNO}_{3}+\mathrm{H}_{2} \mathrm{O}$

- $\quad$ removal by MBM-BA without $\mathrm{pH}$ adjustment (initial $\mathrm{pH} 8.41$, the leftmost data points in Fig. 2c): $\mathrm{MBM}-\mathrm{BA}+\mathrm{K}_{2} \mathrm{HPO}_{4}+$ $\mathrm{H}_{2} \mathrm{O}$

- Acid leaching (data points from control experiments with acid load $0.5-6.0 \mathrm{mM} \mathrm{H}^{+} / \mathrm{g}$ ash in the Figure of Fig. 2e): MBM-BA + $\mathrm{HNO}_{3}+\mathrm{H}_{2} \mathrm{O}$

- Water leaching (control, leftmost data points in the Figure of Fig. 2e): $\mathrm{MBM}-\mathrm{BA}+\mathrm{H}_{2} \mathrm{O}$

- MBM-BA dose: $40 \mathrm{mg} / 40 \mathrm{~mL}, \mathrm{PO}_{4}{ }^{3-}$ dose: $300 \mathrm{mg} / \mathrm{L}$

Fig. 4 Calcium release behaviour during phosphate removal by meat and bone meal ash for selected cases in Figs. $2 \mathrm{c}$ and d: calcium release behaviour (a), $\mathrm{pH}$ (b), and $\mathrm{Ca}$ (released in controls)/P [removed by meat and bone meal ash (MBM-BA)] mole ratio (c). 

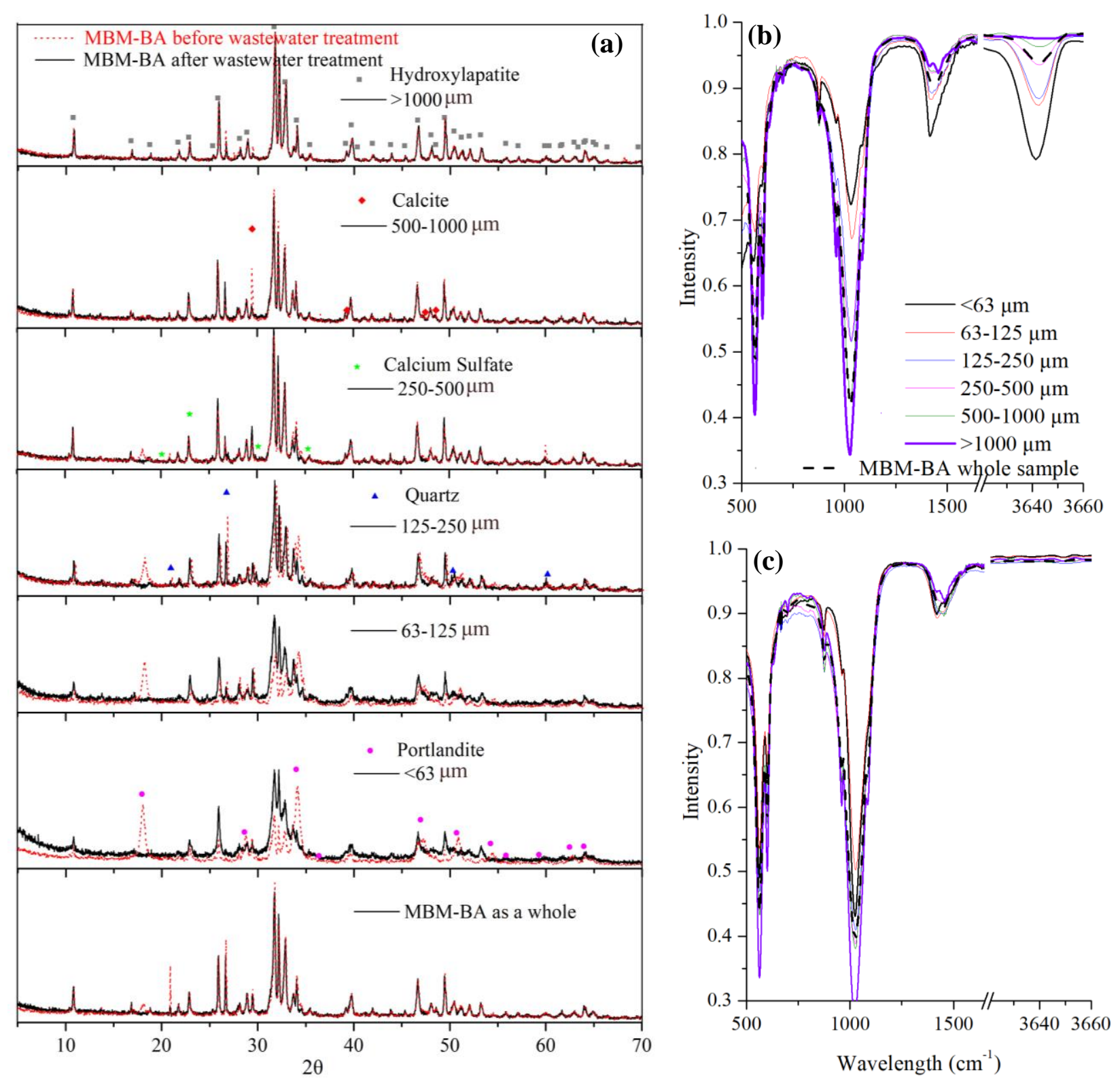

Fig. 5 X-ray powder diffraction (XRD) (a) and Fourier transform infrared spectra (FTIR) analyses (b and c) of meat and bone meal ash (MBM-BA) before and after treatment of P-containing wastewater. 

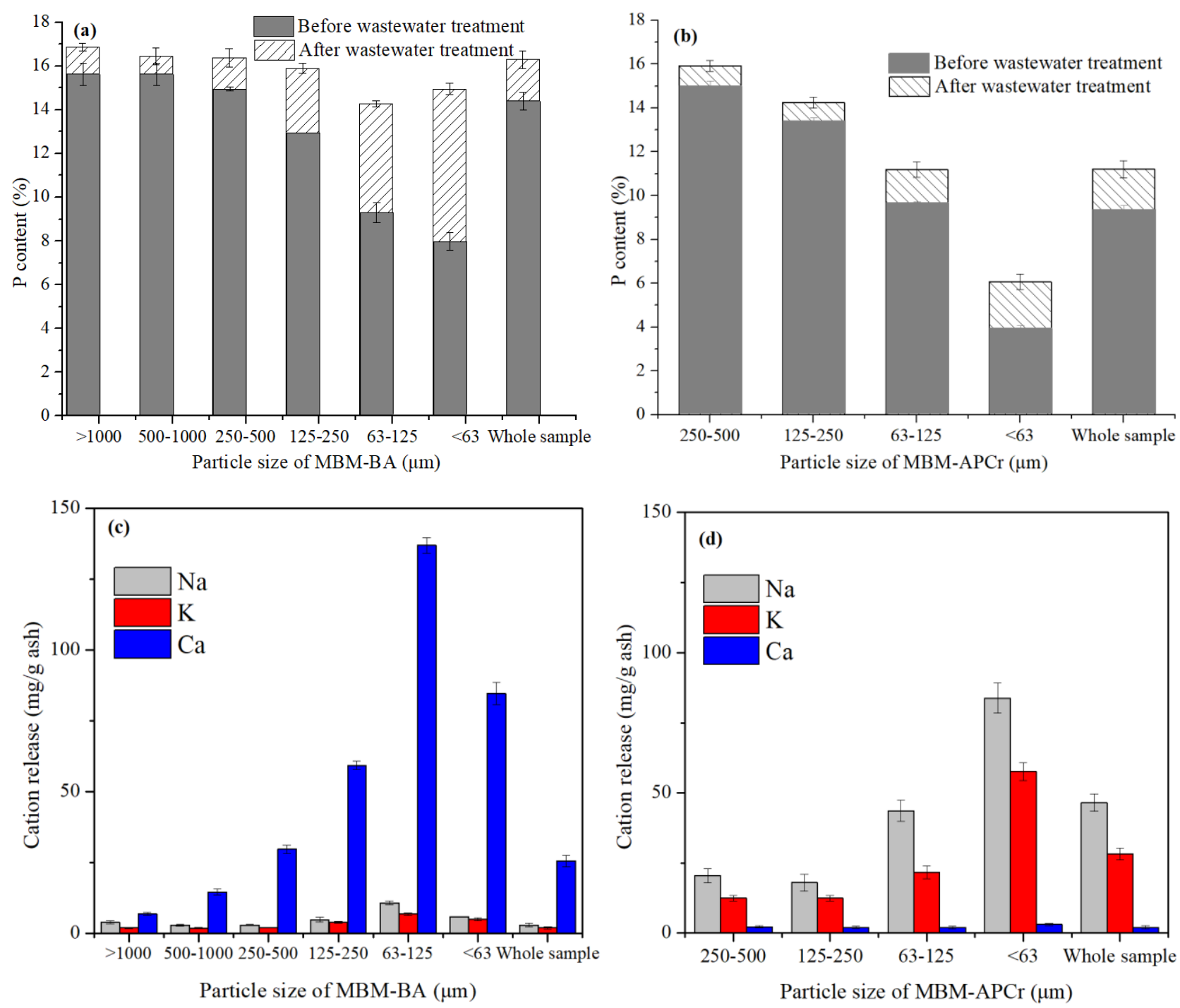

Fig. $6 \mathrm{P}$ content in meat and bone meal bottom ash (a) and air pollution control residue (b) before and after their use for P removal from synthetic phosphate wastewater and the cation release behaviour during the water leaching of meat and bone meal bottom ash (MBM-BA) (c) and air pollution control residue (MBM-APCr) (d). 

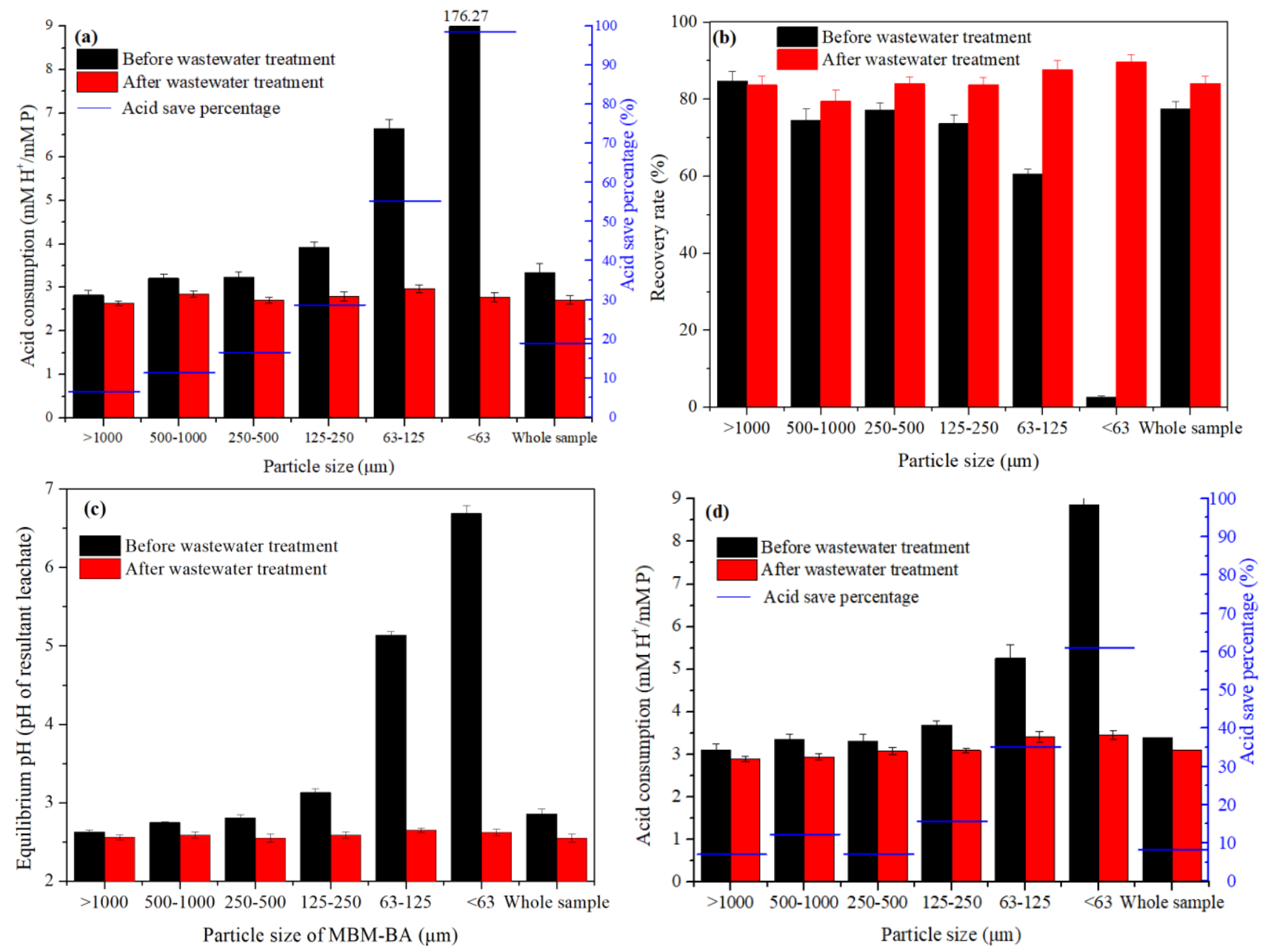

Fig. 7 P recovery from meat and bone meal bottom ash (MBM-BA) before and after its use for removal of $\mathrm{P}$ from synthetic wastewaster: acid consumption (a), $\mathrm{P}$ recovery rate (b), and resultant leachate $\mathrm{pH}$ (c) at acid load $12 \mathrm{mM} \mathrm{H} / \mathrm{g}$ ash; acid consumption at acid load $16 \mathrm{mM} \mathrm{H}^{+} / \mathrm{g}$ ash (d). The number 176.27 in (a) is out of the ordinate and is marked out. 
Table 1 Particle size distribution and elemental compositions of meat and bone meal ash particle size fractions

\begin{tabular}{|c|c|c|c|c|c|c|c|c|c|c|c|c|c|c|c|c|}
\hline \multirow{2}{*}{ Sample } & \multirow{2}{*}{$\begin{array}{l}\text { Mass } \\
(\%)\end{array}$} & \multirow{2}{*}{$\begin{array}{l}\text { Specific } \\
\text { Gravity }\end{array}$} & \multicolumn{8}{|c|}{ Major elements (mg/g) } & \multicolumn{6}{|c|}{ Minor elements (mg/kg) } \\
\hline & & & $\mathrm{Ca}$ & $\mathrm{Na}$ & $\mathrm{K}$ & $\mathrm{Mg}$ & $\mathrm{Al}$ & $\mathrm{Fe}$ & $\mathrm{PP}^{\mathrm{a}}$ & $\mathrm{Ca} / \mathrm{P}^{\mathrm{b}}$ & $\mathrm{Zn}$ & $\mathrm{Cr}$ & $\mathrm{Mn}$ & $\mathrm{Cu}$ & $\mathrm{Ni}$ & $\mathrm{Pb}$ \\
\hline $\begin{array}{l}\text { MBM-BA - } \\
\text { whole sample }\end{array}$ & 100 & 281 & 346 & 16.3 & 4.68 & 5.86 & 1.34 & 2.12 & 143 & 1.87 & 92.7 & 9.61 & 114 & 51.9 & 4.32 & 1.83 \\
\hline$>1000 \mu \mathrm{m}$ & 26.9 & 0 & 345 & 10.1 & 2.94 & 4.06 & 1.05 & 1.06 & 155 & 1.72 & 80.4 & 7.06 & 53.0 & 28.9 & 4.51 & 1.28 \\
\hline $500-1000 \mu \mathrm{m}$ & 29.5 & & 353 & 15.9 & 4.74 & 5.78 & 1.29 & 1.75 & 156 & 1.75 & 76.6 & 8.16 & 80.4 & 33.9 & 4.76 & 4.40 \\
\hline $250-500 \mu \mathrm{m}$ & 23.6 & 2.80 & 355 & 18.2 & 4.86 & 5.88 & 1.29 & 2.14 & 149 & 1.85 & 83.4 & 9.26 & 93.3 & 55.7 & 4.70 & 7.88 \\
\hline & & & 348 & 22.3 & & & & & & & 120 & 12.1 & 119 & 48.3 & & 63.6 \\
\hline $63-125 \mu \mathrm{m}$ & 4.65 & & 333 & 23.0 & 9.03 & 5.97 & & & & & 189 & 15.7 & 128 & 45.7 & 7.38 & 24.1 \\
\hline$<63 \mu \mathrm{m}$ & & & 368 & 17.6 & & 5.70 & & & & & 208 & 31.6 & & 52.7 & 4.33 & 26.7 \\
\hline $\begin{array}{l}\text { MBM-APCr - } \\
\text { whole sample }\end{array}$ & 100 & 2.64 & 206 & 43.0 & 26.1 & 4.18 & 1.05 & 1.80 & 92.8 & 1.72 & 367 & 10.5 & 84.9 & 65.2 & 5.66 & 40.0 \\
\hline $250-500 \mu \mathrm{m}$ & 33.0 & 2.78 & 321 & 33.3 & 23.0 & 4.98 & 1.52 & 2.02 & 149 & 1.67 & 440 & 17.0 & 137.0 & 76.5 & 15.3 & 44.6 \\
\hline $125-250 \mu \mathrm{m}$ & 32.8 & 2.71 & 284 & 45.3 & 26.4 & 3.48 & 1.51 & 1.74 & 133 & 1.65 & 472 & 10.9 & 97.2 & 65.6 & 6.56 & 76.1 \\
\hline $63-125 \mu \mathrm{m}$ & 27.2 & 2.60 & 209 & 62.8 & 26.2 & 5.36 & 1.93 & 2.97 & 95.9 & 1.69 & 639 & 18.6 & 150 & 89.1 & 27.2 & 65.8 \\
\hline$<63 \mu \mathrm{m}$ & 7.12 & 2.52 & 89.7 & 111 & 39.8 & 1.95 & 0.68 & 0.97 & 38.7 & 1.79 & 534 & 12.7 & 52.6 & 72.2 & 4.14 & 78.8 \\
\hline
\end{tabular}

${ }^{\mathrm{a}}$ Total phosphorus; ${ }^{\mathrm{b}}$ mole ratio of $\mathrm{Ca}$ and $\mathrm{P}$. 
Table 2 Calcium phosphate compounds and their solubility product constants (Chow, 2001)

\begin{tabular}{lllr}
\hline Compound & Formula & $\mathrm{Ca} / \mathrm{P}^{\mathrm{a}}$ & $\mathrm{K}_{\text {sp }}$ at $25^{\circ} \mathrm{C}$ \\
\hline Monocalcium phosphate monohydrate & $\mathrm{Ca}\left(\mathrm{H}_{2} \mathrm{PO}_{4}\right)_{2} \cdot \mathrm{H}_{2} \mathrm{O}$ & 0.5 & Highly soluble \\
Monocalcium phosphate anhydrous & $\mathrm{Ca}\left(\mathrm{H}_{2} \mathrm{PO}_{4}\right)_{2}$ & 0.5 & Highly soluble \\
Dicalcium phosphate anhydrous & $\mathrm{CaHPO}_{4}$ & 1.0 & $1.26 \times 10^{-7}$ \\
Dicalcium phosphate dihydrate & $\mathrm{CaHPO}_{4} \cdot 2 \mathrm{H}_{2} \mathrm{O}$ & 1.0 & $2.57 \times 10^{-7}$ \\
$\alpha$-Tricalcium phosphate & $\alpha-\mathrm{Ca}_{3}\left(\mathrm{PO}_{4}\right)_{2}$ & 1.5 & $3.16 \times 10^{-26}$ \\
$\beta$-Tricalcium phosphate & $\beta-\mathrm{Ca}_{3}\left(\mathrm{PO}_{4}\right)_{2}$ & 1.5 & $1.26 \times 10^{-29}$ \\
Hydroxyapatite & $\mathrm{Ca}_{5}\left(\mathrm{PO}_{4}\right)_{3}(\mathrm{OH})$ & 1.67 & $3.98 \times 10^{-59}$ \\
Tetracalcium phosphate & $\mathrm{Ca}_{4}\left(\mathrm{PO}_{4}\right)_{2} \mathrm{O}$ & 2.0 & $1.0 \times 10^{-38}$ \\
\hline
\end{tabular}

${ }^{\mathrm{a}}$ Mole ratio of $\mathrm{Ca}$ to $\mathrm{P}$. 
Table $3 \mathrm{P}$ uptake from waster by meat and bone meal bottom ash (MBM-BA) (circuled points in Figures $2 \mathrm{c}$ and $\mathrm{d}$ )

\begin{tabular}{|c|c|c|c|c|c|}
\hline \multirow[b]{2}{*}{ Particle size } & \multirow{2}{*}{$\begin{array}{l}\text { Acid load for } \\
\mathrm{pH} \text { adjustment } \\
\left(\mathrm{mM} \mathrm{H}^{+} / \mathrm{g} \text { ash) }\right.\end{array}$} & \multirow{2}{*}{$\begin{array}{l}\mathrm{pH} \text { of } \mathrm{P}- \\
\text { containing } \\
\text { wastewater after } \\
\mathrm{pH} \text { adjustment } \\
\text { (before addition } \\
\text { of MBM-BA) }^{\mathrm{a}}\end{array}$} & \multirow{2}{*}{$\begin{array}{l}\mathrm{pH} \text { of } \\
\text { wastewater after } \\
\text { treatment*a }\end{array}$} & \multicolumn{2}{|c|}{$\begin{array}{l}\mathrm{PO}_{4}{ }^{3-} \text { up-take } \\
(\mathrm{mg} / \mathrm{g})^{*}\end{array}$} \\
\hline & & & & $\begin{array}{l}\text { Before } \\
\text { grinding }\end{array}$ & $\begin{array}{l}\text { After } \\
\text { grinding } \\
\text { ash to } \\
<63 \mu \mathrm{m} \\
\end{array}$ \\
\hline $\begin{array}{l}\text { MBM-BA-whole } \\
\text { sample }\end{array}$ & 2.0 & 6.66 & $8.07 \pm 0.05$ & $50.3 \pm 0.8$ & $52.9 \pm 0.5$ \\
\hline$>1000 \mu \mathrm{m}$ & 0.5 & 7.58 & $8.52 \pm 0.12$ & $10.2 \pm 2.3$ & $13.5 \pm 1.2$ \\
\hline $500-1000 \mu \mathrm{m}$ & 1.0 & 7.24 & $8.37 \pm 0.04$ & $21.2 \pm .05$ & $24.1 \pm 0.8$ \\
\hline $250-500 \mu \mathrm{m}$ & 2.0 & 6.66 & $7.95 \pm 0.04$ & $49.5 \pm 0.3$ & $51.4 \pm 0.4$ \\
\hline $125-250 \mu \mathrm{m}$ & 3.0 & 4.08 & $8.03 \pm 0.10$ & $92.9 \pm 2.7$ & $95.7 \pm 4.1$ \\
\hline $63-125 \mu \mathrm{m}$ & 4.0 & 2.80 & $8.19 \pm 0.08$ & $188.4 \pm 3.8$ & $193 \pm 6.2$ \\
\hline$<63 \mu \mathrm{m}$ & 5.0 & 2.65 & $9.93 \pm 0.08$ & $-\mathrm{b}$ & $279 \pm 11$ \\
\hline
\end{tabular}

* Average and standard deviation of three replicates

${ }^{a}$ For MBM-BA after grinding ash fractions to $<63 \mu \mathrm{m}$

${ }^{\mathrm{b}}$ Not available 
Table 4 P removal capacity from wastewater by different materials reported in previous studies

\begin{tabular}{|c|c|c|c|}
\hline Materials & $\begin{array}{l}\text { Intial } \mathrm{PO}_{4}{ }^{3-} \text { concentration, intial } \\
\mathrm{pH} \text {, and temperature of } \\
\text { wastewater }\end{array}$ & $\begin{array}{l}\text { P removal } \\
\text { capacity (mg } \\
\left.\mathrm{PO}_{4}{ }^{3-} / \mathrm{g}\right)\end{array}$ & Reference \\
\hline $\begin{array}{l}\mathrm{Ca}(\mathrm{OH})_{2} \text { pretreated } \\
\text { bentonite }\end{array}$ & $\begin{array}{l}\text { Batch, synthetic wastewater, } \\
500 \mathrm{mg} / \mathrm{L}, \mathrm{pH} 7.6,27-29^{\circ} \mathrm{C}\end{array}$ & 62.3 & $\begin{array}{l}\text { (Markou et al., } \\
\text { 2018) }\end{array}$ \\
\hline $\begin{array}{l}\text { Natural phosphate rock } \\
\text { (apatite) }\end{array}$ & $\begin{array}{l}\text { Batch, synthetic wastewater, } \\
61.3 \mathrm{mg} / \mathrm{L}, \mathrm{pH} 7,22^{\circ} \mathrm{C}\end{array}$ & 14.6 & $\begin{array}{l}\text { (Molle et al., } \\
\text { 2005a) }\end{array}$ \\
\hline $\begin{array}{l}\text { Natural phosphate rock } \\
\text { (apatite) }\end{array}$ & $\begin{array}{l}\text { Column, synthetic wastewater, } \\
3.1-49.0 \mathrm{mg} / \mathrm{L}, \mathrm{pH} 7.6,-^{\mathrm{a}}\end{array}$ & $2.9-5.2$ & $\begin{array}{l}\text { (Harouiya et al., } \\
\text { 2011) }\end{array}$ \\
\hline $\begin{array}{l}\text { Sheep bone pyrolyzed } \\
\text { at } 400{ }^{\circ} \mathrm{C}\end{array}$ & $\begin{array}{l}\text { Batch, synthetic wastewater, } \\
100 \mathrm{mg} / \mathrm{L},-, 21^{\circ} \mathrm{C}\end{array}$ & 30.2 & $\begin{array}{l}\text { (Ghaneian et al., } \\
\text { 2014) }\end{array}$ \\
\hline $\begin{array}{l}\text { Cow bone calcinated at } \\
600{ }^{\circ} \mathrm{C}\end{array}$ & $\begin{array}{l}\text { Batch, synthetic wastewater, } \\
10.7 \mathrm{mg} / \mathrm{L}, \mathrm{pH} 8,25^{\circ} \mathrm{C}\end{array}$ & 9.8 & $\begin{array}{l}\text { (Jang and Kang, } \\
\text { 2002) }\end{array}$ \\
\hline $\begin{array}{l}\text { Meat and bone meal } \\
\text { bottom ash }\end{array}$ & $\begin{array}{l}\text { Batch, synthetic wastewater, } \\
200 \mathrm{mg} / \mathrm{L}, \mathrm{pH} 3-7 \text {, room } \\
\text { temperature }\end{array}$ & 115 & $\begin{array}{l}\text { (Leng et al., } \\
\text { 2019) }\end{array}$ \\
\hline $\begin{array}{l}\text { Meat and bone meal } \\
\text { bottom ash }\end{array}$ & $\begin{array}{l}\text { Batch, synthetic wastewater, } \\
300 \mathrm{mg} / \mathrm{L}, \mathrm{pH} 2.6-7.6,25^{\circ} \mathrm{C}\end{array}$ & $13.5-279$ & The present study \\
\hline
\end{tabular}


Lijian Leng: Conceptualization, Investigation, Methodology, Formal analysis, Writing- Original draft preparation, Review \& Editing, Funding acquisition;

Weijin Zhang: Data Curation, Validation, Review \& Editing; Hailong Li:

Review \& Editing; Anna A. Bogush: Resources, Review \& Editing; Julia A.

Stegemann: Review \& Editing, Supervision, Funding acquisition; Huajun

Huang: Review \& Editing, Resources, Investigation, Funding acquisition. 


\section{Declaration of interests}

$\bigotimes$ The authors declare that they have no known competing financial interests or personal relationships that could have appeared to influence the work reported in this paper.

$\square$ The authors declare the following financial interests/personal relationships which may be considered as potential competing interests:

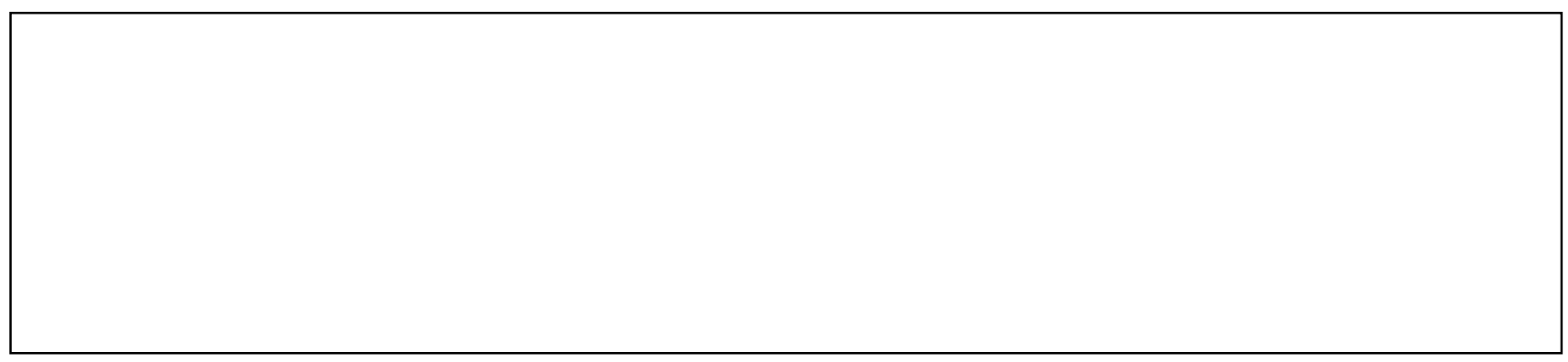

